\title{
Mathematical Modeling for Material Removal and Optimization of Ultrasonic Drilling of Polycarbonate and Acrylic Glass for Surface Roughness by GRA Approach
}

\author{
Kanwal Jeet Singh ${ }^{1, *}$, Inderpreet Singh Ahuja ${ }^{2}$, Jatinder Kapoor ${ }^{3}$ \\ ${ }^{1}$ Department of Mechanical Engineering, Giani Zail Singh Campus College of Engineering and Technology, Bathinda, India \\ ${ }^{2}$ Department of Mechanical Engineering, University College of Engineering, Punjabi University, Patiala, India \\ ${ }^{3}$ Department of Production Engineering, Guru Nanak Dev Engineering College, Ludhiana, India
}

Email address:

khalsa.kanwal@yahoo.com (K. J. Singh), ahujaips@yahoo.co.in (I. S. Ahuja), jatinder_kapur@yahoo.com (J. Kapoor)

*Corresponding author

\section{To cite this article:}

Kanwal Jeet Singh, Inderpreet Singh Ahuja, Jatinder Kapoor. Mathematical Modeling for Material Removal and Optimization of Ultrasonic Drilling of Polycarbonate and Acrylic Glass for Surface Roughness by GRA Approach. International Journal of Mechanical Engineering and Applications. Vol. 5, No. 3, 2017, pp. 136-154. doi: 10.11648/j.ijmea.20170503.12

Received: March 18, 2017; Accepted: April 6, 2017; Published: May 17, 2017

\begin{abstract}
Polycarbonate bullet proof and acrylic heat resistant glasses are used as the functional material in many industrial application. In automobile industries, banks and cabins, polycarbonate bullet proof glass has been used for security purpose. Similarly, acrylic heat resistant glass is used in furnace, microwaves, space craft and airplane applications. In this experimental research paper, Taguchi modal and Grey relational analysis are utilized for the ultrasonic drilling in these materials. For experimentation, input parameters are concentration, abrasive, grit size, power rating, hydrofluoric acid and tool materials. Output parameters are material removal rate, tool wear rate and surface roughness. In which, surface roughness is most significant output parameter, because it describe accuracy of the process. Through optimization analysis, Taguchi modal suggest that $40 \%$ abrasive concentration, mixture of (Alumina, Silicon carbide and Boron carbide) abrasive in 1:1:1, 600 grit of abrasive and $1.5 \%$ hydrofluoric acid gives best results for drilling in polycarbonate bullet proof glass material. Similarly, in acrylic heat resistant glass, mixture of Silicon carbide and Boron carbide (1:1), 600 grit abrasive and $1 \%$ hydrofluoric acid gives the optimum results. Concentration of slurry, abrasive grit size and hydrofluoric acid are the most significant parameters for ultrasonic drilling in both materials. Through Grey relational analysis the surface roughness is improved by $40 \%$ and $48 \%$ in polycarbonate (UL-752) and acrylic (BS-476) glass respectively.
\end{abstract}

Keywords: Polycarbonate, Acrylic, Glass, HF Acid, Taguchi, GRA, USM, Surface Roughness

\section{Introduction}

The history of USM started since 1927 with a research paper reported by A. L. Loomis and R. W. Wood [1, 2, 3, 5, 8, 10]. American engineer Lewis Balamuth in 1945 was granted first patent $[1,2,6,7,8,10]$. USM process have been classified as ultrasonic drilling, ultrasonic cutting, ultrasonic abrasive and ultrasonic dimensional machining [1, 4, 5, 11]. In early 1950's ultrasonic grinding was modified into ultrasonic impact machining $[4,8,9,11]$. It was significant machining process and capable to machine toughest materials $[6,7,10$, $11]$.
The ultrasonic drilling (USM) is generally preferred for amorphous, hard and brittle materials [1, 8]. Through USM, glass, ceramics, titanium, titanium alloys and many more materials are easily machined $[1,2,3,4]$. If the hardness of material is more than $40 \mathrm{HRC}$ then USM is successfully performed $[3,7,10]$. Micro holes as small as $74 \mu \mathrm{m}$ diameter can be easily drilled by USM $[5,9]$. The ratio of depth to diameter is limited to $3: 1[1,4,9,11]$. During USM neither chemical nor thermal changes occur [2, 5, 9]. Moreover, no any metallurgical variations arise on work surface $[2,4,5,10]$. 
In USM process, power supply have an important role. It convert low frequency electrical signals into high frequency electrical signals $[2,3,8,9,11,15,24,26]$. After that these signals are transmitted to transducer. Two type of transducer are generally used, magnetostatic and piezoelectric transducer $[8,9,10,11,19,24,28]$. The transducer converts high frequency electrical signals into mechanical vibrations $[5,14,19,21,24]$. Through horn, the effect of vibrations are amplified and concentrate on tool assembly [4, 8, 9, 15, 24]. USM tool vibrates along its longitudinal axis with ultrasonic frequency between $20 \mathrm{kHz}$ to $40 \mathrm{kHz}[3,10,11,26,28,30]$. The amplitude of vibrations are measured in few hundredth of millimeters along longitudinal axis of tool $[1,9,15,19]$. Horn and tool must be designed with mass and shape considerations, so that the resonance effect can be achieved with in the frequency range $[2,10,11,12,28,30,41,43]$.

Power rating of USM varies in between $50 \mathrm{~W}$ to $4000 \mathrm{~W}$ [5, 19, 21, 37]. Along longitudinal axis controlled static load is applied on the USM tool $[6,8,19,25,38,40]$. Mixture of abrasive and carrier medium is known as slurry $[18,27]$. The concentration of slurry varies from $30 \%$ to $50 \%$ by volume [ 1 , $3,8,9,12,30,31,40,41,42,62]$. It is pumped in between the gap of tool and work surface. The optimum pumping speed of slurry is $30 \mathrm{litter} / \mathrm{min}[3,9,12,41]$. Water is commonly used as a carrier medium $[2,8,12,28,42,43,44,45,46]$. Because, it have low viscosity, low density, high thermal conductivity and high specific heat characteristics [8, 11, 12 35, 45, 46]. Most preferable abrasives are boron carbide, alumina, silicon carbide and diamond dust [2, 9, 12, 13, 34, 62]. Abrasive particles are forced by tool vibrations to strike on work surface $[14,37,49,51]$. The impact of abrasive particles supports to erode the material in the form of micro-chips $[5,8,10,13,28$, 62]. The shape of cavity is similar to the USM tool $[1,2,5,8$, $10,13,14,45]$. Volumetric material removal rate of USM is relatively low $[9,18,22,29,37,58]$. Figure 1 shows the schematic diagram of simple USM [2, 3, 9, 30, 45]. The new approach of USM is CNC controlled path rotary USM [1, 9, 10, 13, 40, 41]. SONEX300 extrude horn made in France, EROSONIC US400 and EROSONIC US800 manufactured by Sonic Mill and made in USA are commonly used on commercial level [1, 8, 13, 62].

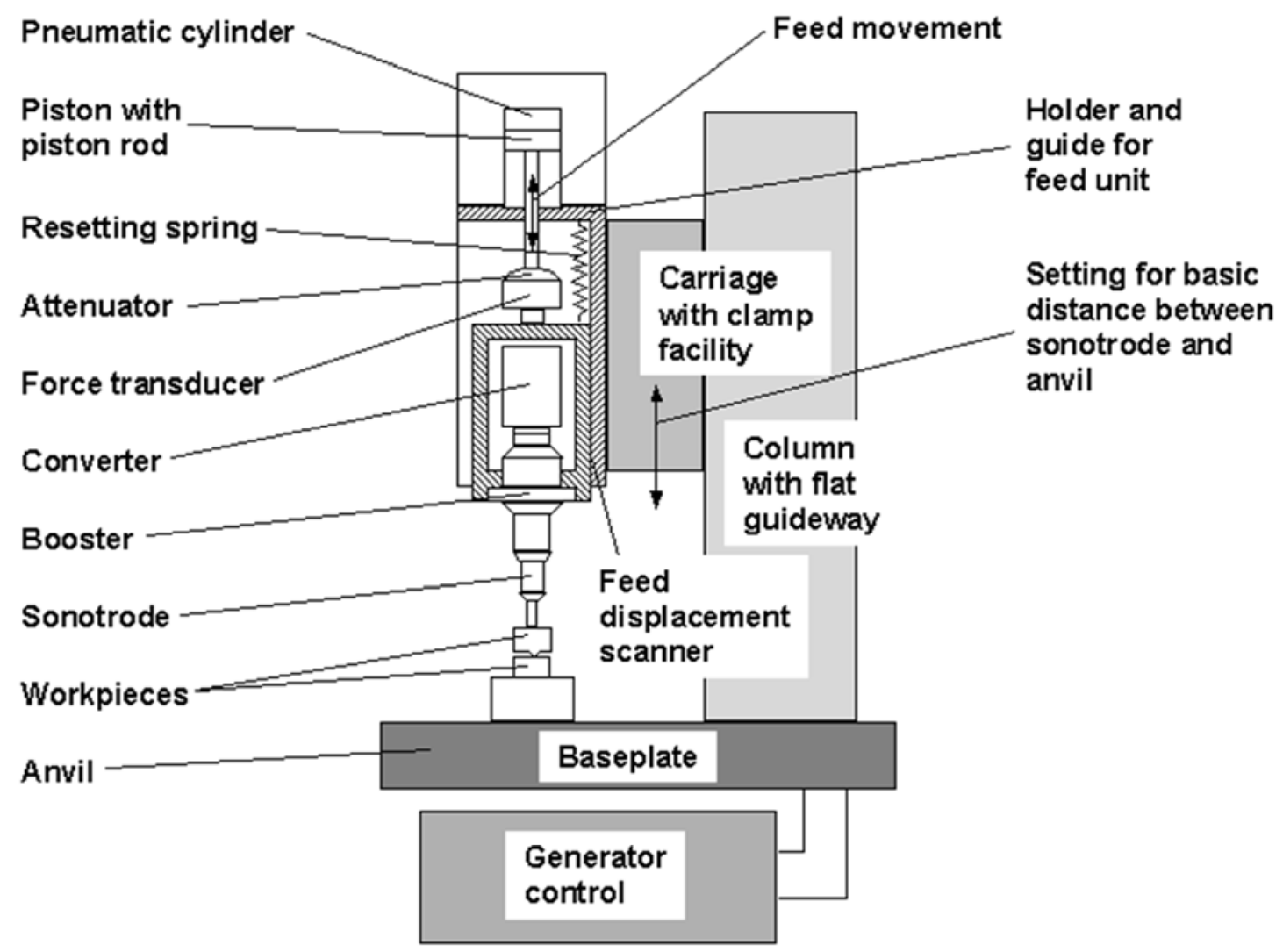

Figure 1. Schematic diagram of simple USM.

The USM machine is available in small tabletop sized units. The different type of accessories are used for suitability of operation. Appropriate type of USM is determined through capacity of power rating $[2,7,10,31,47,51,53]$. Figure 2 shows the $500 \mathrm{~W}$ USM machine manufactured by Sonic Mill and made in USA, which is used for small operation $[7,12]$. The horn transfer mechanical vibration energy from transducer to tool $[5,10,14,19,37,48]$. It also amplify the mechanical vibration effect. The horn material must have high fatigue, toughness and elastic properties [1, 13, 19, 38, 41]. Generally preferred material for horn are silver steel, monal and tungsten carbide [2, 17, 24, 38, 61]. Copper washer is introduced in between the transducer-horn and horn-tool fastening, to prevent unnecessary ultrasonic welding $[8,12,15$, $16,28,37,42,49,51]$. 


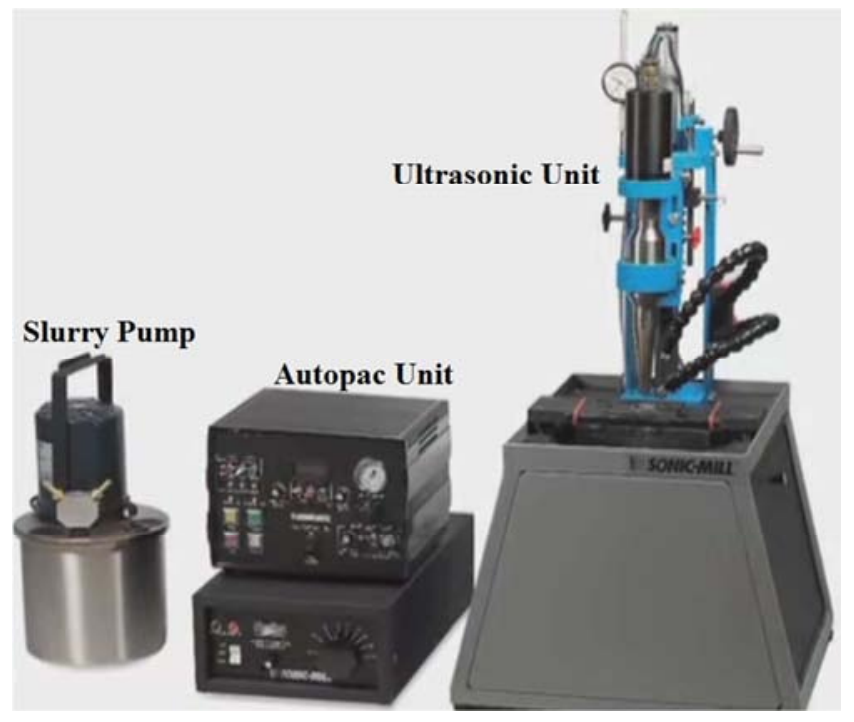

Figure 2. $500 \mathrm{~W}$ USM machine manufactured by Sonic Mill and made in USA.

\section{Material Removal Mechanism}

\subsection{Traditional Ultrasonic Machining}

Material removal primarily occurs due to the indentation of the hard abrasive grits on the brittle work material. As the tool vibrates, it leads to indentation of the abrasive grits $[5,9,16]$. During indentation, due to Hertzian contact stresses, cracks would develop just below the contact site, then as indentation progresses the cracks would propagate due to increase in stress and ultimately lead to brittle fracture of the work material under each individual interaction site between the abrasive grits and the work-piece [2, 15, 19, 27, 39, 42, 61]. The tool material should be such that indentation by the abrasive grits does not lead to brittle failure. Thus the tools are made of tough, strong and ductile materials like steel, stainless steel and other ductile metallic alloys $[15,19,37,48,51,61$, $62,64]$

Other than this brittle failure of the work material due to indentation some material removal may occur due to free flowing impact of the abrasives against the work material and related solid-solid impact erosion, but it is estimated to be rather insignificant $[19,58,63,65,66,67]$. Thus, in the current model, material removal would be assumed to take place only due to impact of abrasives between tool and workpiece, followed by indentation and brittle fracture of the workpiece. The model does consider the deformation of the tool.

In the current model, all the abrasives are considered to be identical in shape and size $[19,28,64,68,69,70]$. An abrasive particle is considered to be spherical but with local spherical bulges as shown in figure 3 The abrasive particles are characterized by the average grit diameter, $d_{g}[37,59,65,69$, $71,72]$. It is further assumed that the local spherical bulges have a uniform diameter, $d_{b}$ and which is related to the grit diameter by $d_{b}=\mu d_{g}{ }^{2}$. Thus an abrasive is characterized by $\mu$ and $\mathrm{d}_{\mathrm{g}}$.

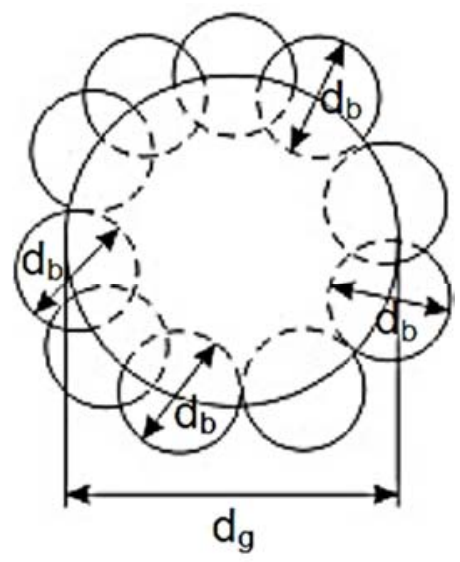

Figure 3. Schematic representation of abrasive grit.

During indentation by the abrasive grit onto the work-piece and the tool, the local spherical bulges contact the surfaces and the indentation process is characterized by $d_{b}$ rather than by $d_{g}$ $[14,19,28,37,43,55,61,68,72,73]$. Fig. 4 shows the interaction between the abrasive grit and the work-piece and tool.

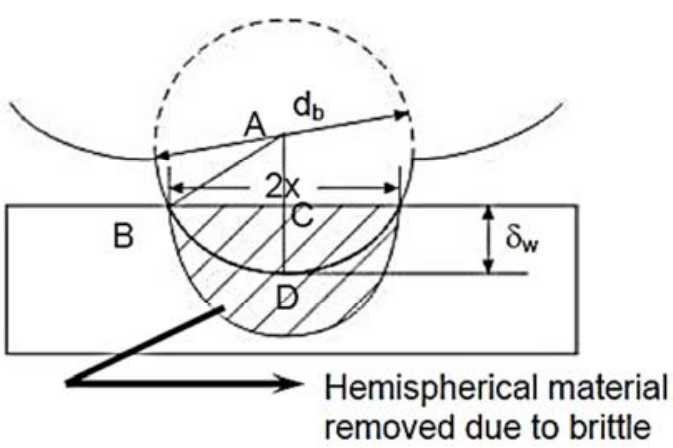

Figure 4. Interaction between grit and work-piece and tool.

As the indentation proceeds, the contact zone between the abrasive grit and work-piece is established and the same grows $[15,37,48,68,69,70,73]$. The contact zone is circular in nature and is characterized by its diameter ' $2 x$ '. At full indentation, the indentation depth in the work material is characterized by $\delta_{\mathrm{w}}$. Due to the indentation, as the work material is brittle, brittle fracture takes place leading to hemi-spherical fracture of diameter ' $2 x$ ' under the contact zone. Therefore material removal per abrasive grit is given as 


$$
\Gamma_{w}=\frac{2}{3} \pi X^{3}
$$

Now From Figure $4 \mathrm{AB}^{2}=\mathrm{AC}^{2}+\mathrm{BC}^{2}$

$$
\begin{gathered}
\left(\frac{d_{b}}{2}\right)^{2}=\left(\frac{d_{b}}{2}-\delta_{x}\right)^{2}+X^{2} \\
X^{2}=d_{b} \delta_{w} \text { Negecting. } \delta_{w}{ }^{2} \text { as } \delta_{w}<d_{b} \\
\Gamma_{w}=\frac{2}{3} \pi\left(d_{b} \delta_{w}\right)^{\frac{3}{2}}
\end{gathered}
$$

If at any moment of time, there are an average ' $n$ ' of grits and the tool is vibrating at a frequency ' $\mathrm{f}$ ' then material removal rate can be expressed as

$$
\begin{gathered}
M R R_{w}=\Gamma_{w} . n \cdot f \\
M R R_{w}=\frac{2}{3} \pi\left(d_{b} \delta_{w}\right)^{\frac{3}{2}} . n \cdot f
\end{gathered}
$$

Now as the tool and workpiece would be pressing against each other, contact being established via the abrasive grit, both of them would deform or wear out. As the tool vibrates, for some time, it vibrates freely; then it comes in contact with the abrasive, which is already in contact with the job, and then the indentation process starts and finally completes with an indentation of $\delta_{\mathrm{w}}$ and $\delta_{\mathrm{t}}$ on the work and tool respectively. Figure 5 schematically depicts the same assuming the work to be rigid for easy depiction. The tool vibrates in a harmonic motion $[59,61,63,69,74,75,76]$. Thus only during its first quarter of its cycle it can derive an abrasive towards interaction with the tool and work-piece as shown in Figure 6
Out of this quarter cycle, some part is used to engage the tool with abrasive particle as shown in Figure 6 Thus the time of indentation $\tau$ can be roughly estimated as

$$
\frac{\delta}{a_{0}}=\frac{\tau}{T / 4} \Rightarrow \tau=\frac{T \delta}{4 a_{0}}=\frac{T\left(\delta_{w}+\delta_{t}\right.}{4 a_{0}}
$$

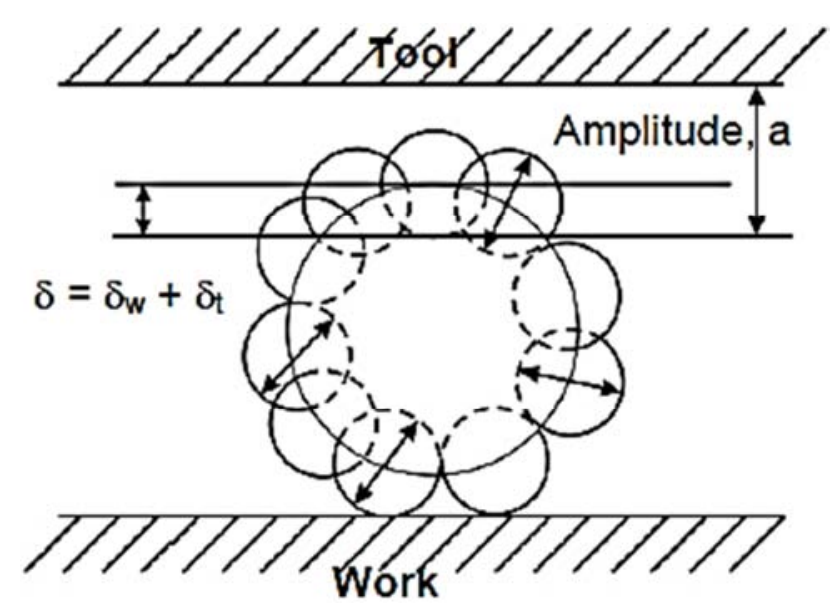

Figure 5. Interaction between grit and work-piece and tool to depict the work-piece and tool deformations.

Now during machining, the impulse of force on the tool and work would be balanced. Thus total impulse on the tool can be expressed as

$$
l_{t}=n \cdot f \cdot \frac{1}{2} F_{\max } \tau
$$

where $F_{\max }$ is the maximum indentation force per abrasive.

Now in the USM, the tool is fed with an average force F

$$
F=\frac{1}{2} F_{\max } \tau . n . f
$$

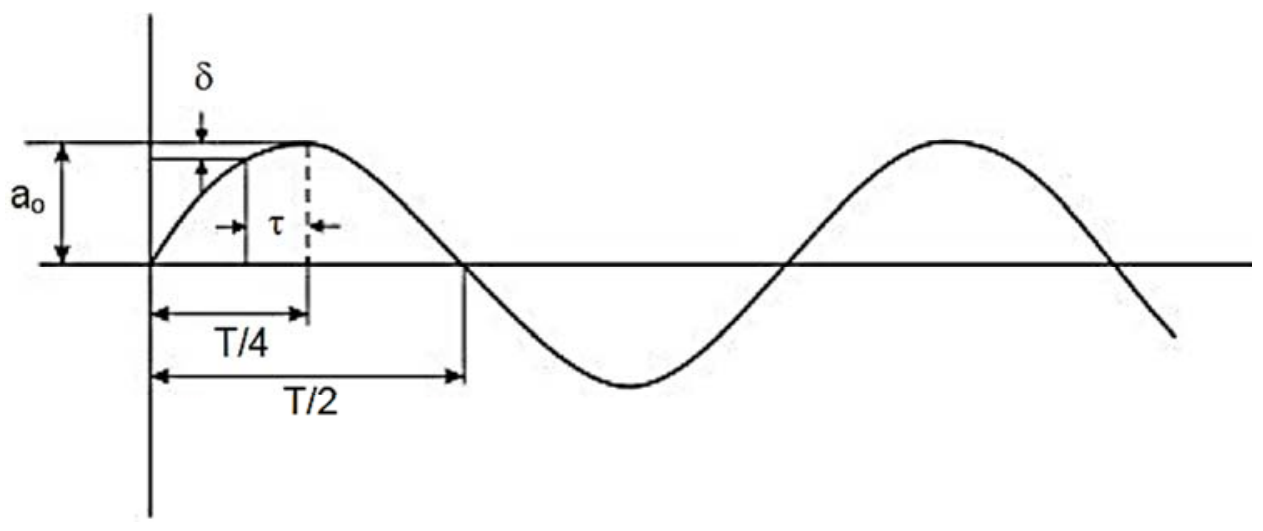

Figure 6. Change in tool position due to ultrasonic vibration of the tool.

Again, if the flow strength of work material is taken as $\sigma_{\mathrm{w}}$, then

$$
F_{\max }=\sigma_{w} \pi X^{2}
$$




$$
F=\frac{1}{2} n \cdot f \cdot \sigma_{w} \pi X^{2} \frac{T\left(\delta_{w}+\delta_{t}\right)}{4 a_{0}}
$$

If ' $A$ ' is total surface area of the tool facing the work-piece, then volume of abrasive slurry of one grit thickness is

$\mathrm{A} \mathrm{d}_{\mathrm{g}}$

If $\mathrm{n}$ is the number of grits then the total volume of $\mathrm{n}$ grits is

$$
\frac{\pi d_{g}^{3}}{6} n
$$

Thus the concentration of abrasive grits in the slurry is related as follows:

$$
\begin{gathered}
n \frac{\pi d_{g}{ }^{3}}{6}=A d_{g} C \\
C=\frac{n \frac{\pi d_{g}^{3}}{6}}{A d_{g}}=\frac{\pi d_{g}{ }^{3}}{6 A} n \\
n=\frac{6 A C}{\pi d_{g}^{2}} n
\end{gathered}
$$

Now it is expected that indentation would be inversely proportional to the flow strength then,

$$
\frac{\delta_{t}}{\delta_{w}}=\frac{\sigma_{w}}{\sigma_{t}}=\lambda
$$

Again combining, ' $F$ ' can be written as

$$
\begin{gathered}
F=\frac{1}{2} \sigma_{w} \pi X^{2} \tau . n . f \frac{T}{4 a_{0}} \delta_{w}(1+\lambda) \\
F=\frac{1}{2} \frac{6 A C}{\pi d_{g}^{2}} f . \sigma_{w} \pi d_{b} \delta_{w} \frac{T}{4 a_{0}} \delta_{w}(1+\lambda) \\
F=\frac{3 A C}{d_{g}^{2}}(f . t) \frac{\sigma_{w}}{4 a_{0}} d_{b} \delta_{w}^{2}(1+\lambda) \\
F=\frac{3 A C}{d_{g}^{2}}(f . t) \frac{\sigma_{w}}{4 a_{0}} \mu d_{g}^{2} \delta_{w}^{2}(1+\lambda) \\
\delta_{w}^{2}=\frac{4 a_{0} F}{3 \mu A C \sigma_{w}(1+\lambda)} \\
M R R_{w}=\Gamma_{w} . n . f
\end{gathered}
$$

$$
\begin{aligned}
& =\frac{2}{3} \pi X^{3} n . f \\
& =\frac{2}{3} \pi \frac{6 c A}{\pi d_{g}^{2}} \cdot f \cdot X^{3} \\
& =4 \pi \frac{c A}{\pi d_{g}^{2}} \cdot f \cdot\left(d_{w} \delta_{w}\right)^{\frac{3}{2}} \\
& =\frac{4 c A}{d_{g}^{2}} \cdot f \cdot\left(\mu \cdot d_{g}^{2} \delta_{w}\right)^{\frac{3}{2}} \\
& =4 c A d_{g} \mu^{\frac{3}{2}} \cdot f \cdot\left\{\frac{4 F a_{0}}{3 \mu A c \sigma_{w}(1+\lambda)}\right\}^{\frac{3}{4}} \\
& \alpha \frac{c^{\frac{1}{4}} A^{\frac{1}{4}} F^{\frac{3}{4}} a_{0}^{\frac{3}{4}} d_{g} f}{\sigma_{w}^{\frac{3}{4}}(1+\lambda)^{\frac{3}{4}}} \mu^{\frac{3}{4}} \\
& \alpha . d_{g} \cdot f \cdot \frac{c^{\frac{1}{4}} A^{\frac{1}{4}} \rho^{\frac{3}{4}} a_{0}^{\frac{3}{4}}}{\sigma_{w}^{\frac{3}{4}}(1+\lambda)^{\frac{3}{4}}} \mu^{\frac{3}{4}}
\end{aligned}
$$

Mechanism of material removal or erosion is investigated by various researcher $[1,2,3,12,15,16,17,19,40,45,65,77$, $78,79,80,81]$. Figure 7 shows basic mechanism of material removal process in USM. For brittle and hard material, fracture effect produced the erosion. Similarly, shearing effect is utilized for ductile materials. Erosion effect is produced through bombardment of abrasive particles directly against the work surface $[12,16,17,28,30,31,79,80,81,82]$. Appropriate flow of slurry will enhanced the material removal rate $[2,12,17,19,22,24,26,65]$. Cavitation effect is also formed by slurry, which reduce the material removal rate [19, $20,40,46]$. Material is removed in the form of micro-chips and flush out with slurry [20, 22, 46, 65].

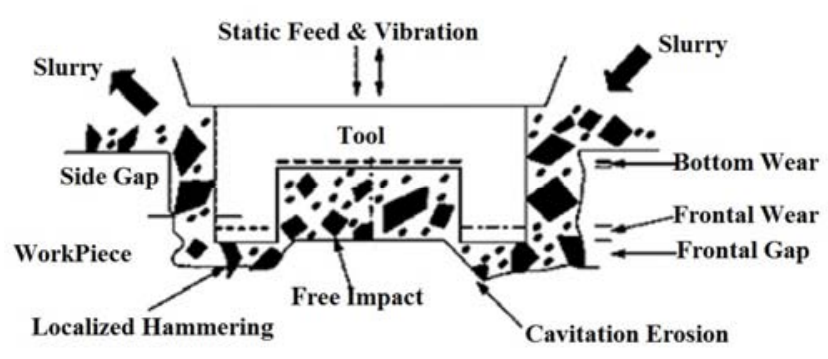

Figure 7. Basic mechanism of material removal process in simple USM.

\subsection{Chemical-Assisted Ultrasonic Machining}

In chemical-assisted ultrasonic machining (CUSM), low 
concentration of hydrofluoric acid (HF) is used in slurry. HF acid reaction between $\mathrm{Si}$ and $\mathrm{F}^{-}$ions and $\mathrm{O}$ and $\mathrm{H}^{+}$occur simultaneously. When HF acid react with glass then the bonding forces between $\mathrm{Si}$ molecules on the surface area become weakened. This mechanism improve the efficiency of USM $[7,11,12,13,14,21]$. Figure 8 shows Basic mechanism of material removal process in chemical
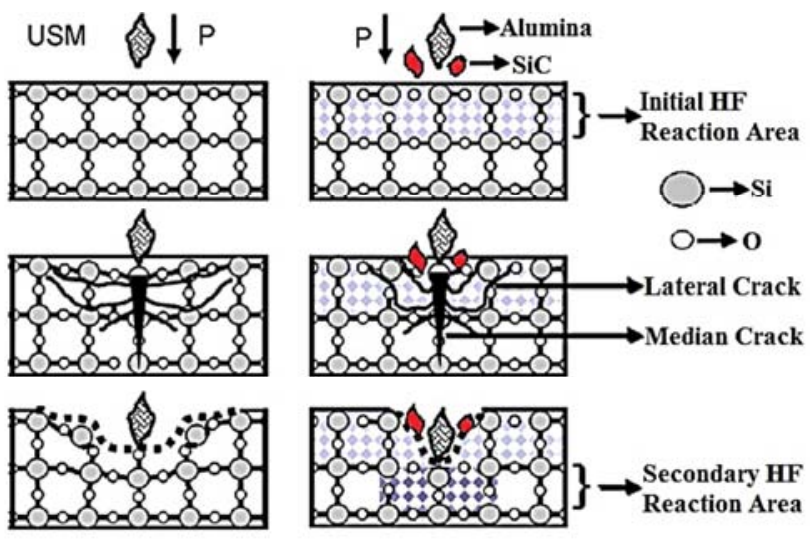

Figure 8. Basic mechanism of material removal process in chemical.

\section{Type of Glass and Application}

Glass is non-crystalline or amorphous material. It is transparent by appearance and used in many appliances such as window panels, optoelectronics, technological equipment, optical etc. [65, 66, 67, 69]. The main ingredient of glass is silica (sand) [68]. Many silica based glasses are exist such as container glass and ordinary glass, which are manufactured by specific type of soda-lime glass. The main composition of soda-lime glass is approximately $75 \% \mathrm{SiO}_{2}$ (silicon dioxide), $\mathrm{Na}_{2} \mathrm{CO}_{3}$ (sodium carbonate), $\mathrm{Na}_{2} \mathrm{O}$ (Sodium oxide), $\mathrm{CaO}$ (calcium oxide or lime) and some minor other additives [67, 68, 69].

Window panels are generally manufactured by silicate glasses. Glass reflect as well as transfer light from own self. These reflection and transformation quality is utilized to make prisms, optical fiber, lenses and fine glasses.

Optical fiber are used for high speed data transmission. The color of the glass is changed by adding some ingredient like metallic salt, zinc etc. $[68,70,71]$. These type of colored glass is used in manufacturing the art object, stained glass window, color glass window and many more applications. Glass is easily formed or molded into any required shape, so it is traditionally used in the manufacturing of bowls, jars, vases, bottles and drinking jars. The most hard and solid form of simple silicate glass used for marbles, beads and paperweights $[71,72,74,75]$.

The other modern example of the glass is glass fiber, the glass is extrude under the high temperature and converted into the fiber glass or glass wool. Glass fiber have property of data transferred at the speed of light. Glass wool is used as the thermal insulating material $[73,76,77,78,79]$. The other application of glass fiber, it is used as the reinforcement material in the composite material fiber glass. Many thermoplastic and porcelains material are the closer familiar to the glasses. The addition of these closer familiar material improve the properties of the silicate glass. Acrylic glass, polyethylene, terephthalate and polycarbonate these are the lighter alternative of the simple silicate glasses [67, 71, 77, 79].

\subsection{Polycarbonate and Acrylic Glass}

Polycarbonate bullet proof glass, acrylic heat resistant glass and glass-clad polycarbonate bullet proof glass are the advanced types of glass [78, 80, 81]. These glasses are manufactured by affixing two different materials through epoxy resin liquid $[82,84,86]$. In polycarbonate bullet proof glass, layers of glass and polycarbonate materials are affixed with each other. Number of layers are defined according to the bare load [85]. Elastic effect is produced by polycarbonate material during impact load [87, 88, 89]. Thickness of polycarbonate bullet proof glass is varies from $10 \mathrm{~mm}$ to 76 $\mathrm{mm}[68,71,88,90]$. Similarly in acrylic heat resistant glass, layers of glass and acrylic material are affixed with each other through epoxy resin $[90,91,92]$. Acrylic glass is also known as poly (methyl methacrylate) or PMMA material. It is a transparent thermoplastic often used in sheet form as a lightweight, shatter resistant and heat resistant material [71]. Acrylic (PMMA) material of $3 \mathrm{~mm}$ thick sheet can transmits up to $92 \%$ of visible light. It have poor thermal conductivity $[72,76,83]$. Thickness of acrylic heat resistant glass is varies from $85 \mathrm{~mm}$ to $150 \mathrm{~mm}$. Table 1 shows some important properties of polycarbonate bullet proof glass and acrylic heat resistant glass [76, 83, 86, 87, 89]. Table. 2 shows Thickness and density of advanced glass material

Glass have poor elasticity property, mean it can't deformed when force applied on it $[72,85]$. Plain glass under impacted by bullet, in which impact load of bullet break the plain glass [71, 91, 92,]. First layer of glass may shatter when the bullet hits it, however the next layer of polycarbonate is more elastic so it moves when the bullet strike. Impact energy of bullet is dissipates vertically $[84,85,90,91,92,93,95]$. This takes the energy away from the bullet and it slowing down. If the enough energy is taken from the bullet, it will eventually stop it from passing through [69]. Some important properties of these material make them so famous and the utility of these materials are increased in present era $[69,70,71,90,94,95$, 96, 97, 98]. Figure 10 shoes the acrylic heat resistant glass material. 
Table 1. Important properties of polycarbonate bullet proof and acrylic heat resistant glass.

\begin{tabular}{lll}
\hline Properties & PBPG (UL-752) & AHRG (BS-476) \\
\hline Physical Properties & & $8.3 \mathrm{~g} / \mathrm{cm}^{3}$ \\
Density & $7 \mathrm{gm} / \mathrm{cm}^{3}$ & 29.7 \\
Refractive Index & 34.0 & $\mathrm{~V}_{0}-\mathrm{V}_{4}$ \\
Flammability & $\mathrm{V}_{0}-\mathrm{V}_{2}$ & $31-34 \%$ \\
Limiting Oxygen Index & $25-27 \%$ & $0.12-0.41 \%$ \\
Water Absorption & $0.16-0.35 \%$ & Fair \\
Radiation Resistant & Fair & $1.8-2.2 \mathrm{GPa}$ \\
Mechanical Properties & & $105-155 \mathrm{MPa}$ \\
Young's Modulus & $2.0-2.4 \mathrm{GPa}$ & $1200 \mathrm{MPa}\left(\mathrm{at} 73^{\circ} \mathrm{F}\right)$ \\
Tensile strength (Depend on thickness) & $120-180 \mathrm{MPa}$ & $8.23 \times 10^{-6} \mathrm{~m} /(\mathrm{m}-\mathrm{k})$ \\
Compressive Strength & $1000 \mathrm{MPa}\left(\mathrm{at} 73^{\circ} \mathrm{F}\right)$ & $0.86 \mathrm{~W} /(\mathrm{m}-\mathrm{K})$ \\
Linear expansion $\left(20-300^{\circ} \mathrm{C}\right)$ & $9 \mathrm{x} 10^{-6} \mathrm{~m} /(\mathrm{m}-\mathrm{k})$ & $\mathrm{poor}$ \\
Thermal Conductivity & $0.30 \mathrm{~W} /(\mathrm{m}-\mathrm{K})$ & $61 \mathrm{HRC}$ \\
Reactivity with HF Acid & poor & $158^{\circ} \mathrm{C}$ \\
Hardness & $58 \mathrm{HRC}$ & $0.09-0.13 \mathrm{~W} /(\mathrm{m}-\mathrm{K})$ \\
Thermal Properties & & \\
Glass Transition Temperature & $147^{\circ} \mathrm{C}$ & Poor \\
Thermal Conductivity at $23^{\circ} \mathrm{C}$ & $0.19-0.22 \mathrm{~W} /(\mathrm{m}-\mathrm{K})$ & $\mathrm{Good}$ \\
Chemical Resistance Properties & & Poor \\
Acids (Concentrated), Halogens, Ketones and Aromatic Hydrocarbons & Poor & Good \\
Acid (Dilute) and Alcohols & Fair & \\
Greases, Oils and Halogenated & & \\
\hline
\end{tabular}

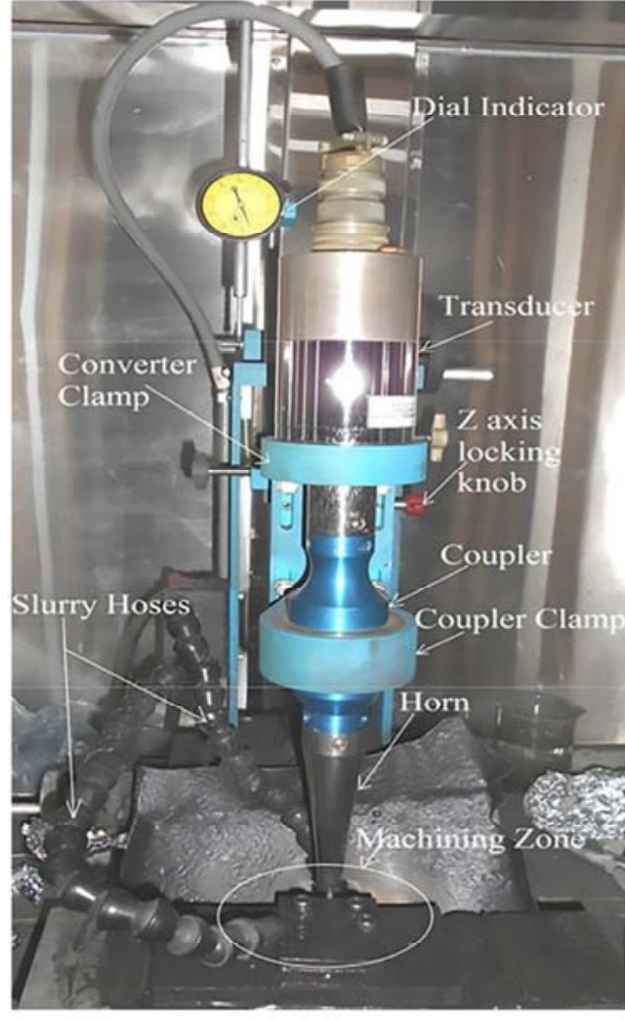

(a)

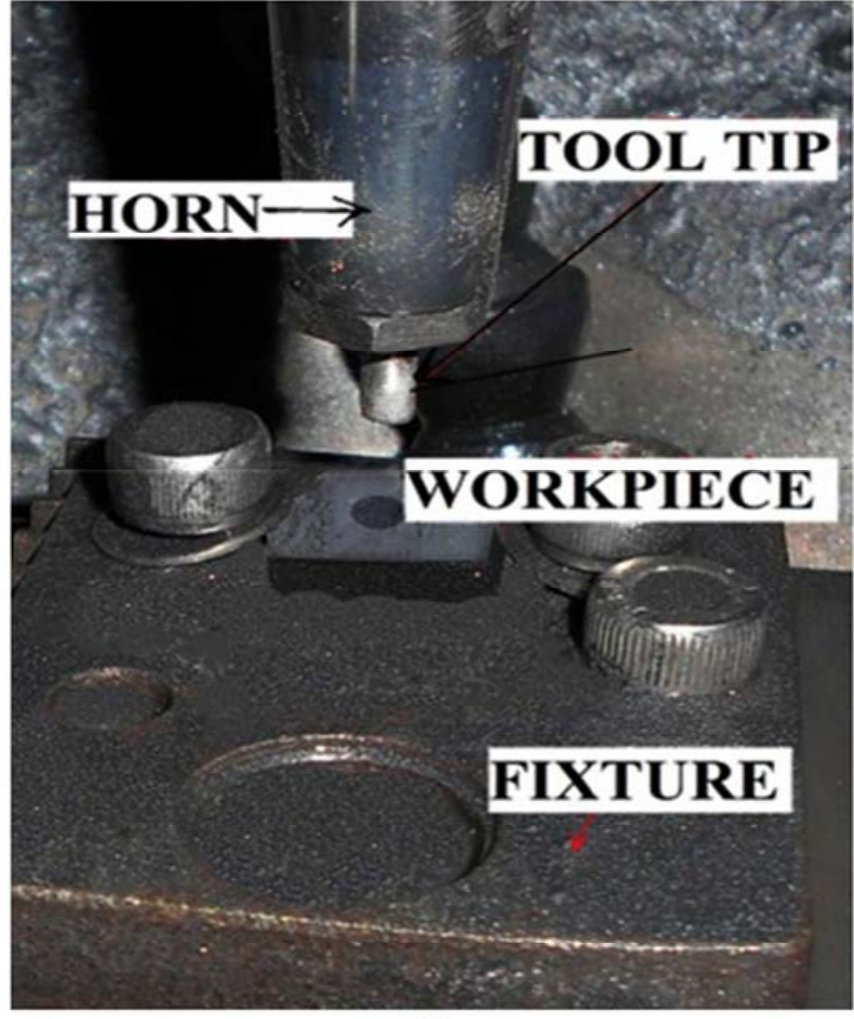

(b)

Figure 9. Different components of USM and enlarged view of cutting zone.

Table 2. Thickness and density of advanced glass material.

\begin{tabular}{|c|c|c|c|c|c|c|c|}
\hline \multirow{2}{*}{$\begin{array}{l}\text { Protection level } \\
\text { UL } 752\end{array}$} & \multirow{2}{*}{$\begin{array}{l}\text { Threat Stopped } \\
3 \text { short }(\mathrm{mm})\end{array}$} & \multicolumn{2}{|c|}{ Polycarbonate Glass } & \multicolumn{2}{|c|}{ Acrylic Glass } & \multicolumn{2}{|c|}{ Glass Clad PC Glass } \\
\hline & & $\begin{array}{l}\text { Thickness } \\
\text { (inch) }\end{array}$ & $\begin{array}{l}\text { Density } \\
\left(\mathrm{Kg} / \mathrm{m}^{2}\right)\end{array}$ & $\begin{array}{l}\text { Thickness } \\
\text { (inch) }\end{array}$ & $\begin{array}{l}\text { Density } \\
\left(\mathrm{Kg} / \mathrm{m}^{2}\right)\end{array}$ & $\begin{array}{l}\text { Thickness } \\
\text { (inch) }\end{array}$ & $\begin{array}{l}\text { Density } \\
\left(\mathrm{Kg} / \mathrm{m}^{2}\right)\end{array}$ \\
\hline Level I & $9 \mathrm{~mm}$ & 0.76 & 22.5 & 1.26 & 37.7 & 0.81 & 44.1 \\
\hline Level II & .36 Magnum & 1.04 & 31.3 & 1.38 & 41.6 & 1.07 & 57.1 \\
\hline Level III & .45 Magnum & 1.26 & 37.7 & & & 1.28 & 69.4 \\
\hline Level IV & .30 Caliber 1 short & & & & & 1.39 & 69.4 \\
\hline
\end{tabular}


The experiments were performed on 500 W USM machine manufactured by Sonic mill and made in USA, which is used for small operation. The different components of USM machine and enlarged view of cutting zone are shown in figure 9 (a) and 9 (b). Input parameters and fixed parameters for investigation are shown in table 3 . Surface roughness is measured is $R_{a}$, it is the universally recognised and most used international parameter of roughness. It is the arithmetic mean of the absolute departure of the roughness profile from the mean line.

Table 3. Input parameters and fixed parameters for investigation.

\begin{tabular}{llll}
\hline Input Parameters & & & \\
\hline \multirow{2}{*}{ Factor (Symbols) } & Levels & Level 2 & Level 3 \\
\cline { 2 - 4 } & Level 1 & $30 \%$ & $40 \%$ \\
\hline Concentration (A) & $20 \%$ & $\mathrm{SiC}+\mathrm{B}_{4} \mathrm{C}$ & $\mathrm{Al}_{2} \mathrm{O}_{3}+\mathrm{SiC}+\mathrm{B}_{4} \mathrm{C}$ \\
Abrasive (B) & $\mathrm{Al}_{2} \mathrm{O}_{3}+\mathrm{B}_{4} \mathrm{C}$ & $40 \%$ & $60 \%$ \\
Power Rate (C) & $20 \%$ & 400 & 600 \\
Grit Size (D) & 280 & $1 \%$ & $1.5 \%$ \\
HF Acid (E) & $0.5 \%$ & $\mathrm{HCS}$ & $\mathrm{HSS}$ \\
Tool Material (F) & $\mathrm{D} 2$ & & $25^{\circ} \mathrm{C}$ \\
Fixed Parameters & & Slurry Temperature & 30 litter $/$ min \\
Frequency & $20 \mathrm{kHz}$ & Slurry flow rate & \\
Static load & $1.63 \mathrm{~kg}$ & & \\
Amplitude of vibration & $25.3-25.8 \mu \mathrm{m}$ & & \\
\hline
\end{tabular}

\section{Experimentation and Data Collection}

Taguchi's $\mathrm{L}_{27} \mathrm{OA}$ was used for experimental design. There are six input factors with three different levels. In addition, two interaction ( $\mathrm{B} \times \mathrm{E}$ and $\mathrm{B} \times \mathrm{F}$ ) are also required to be evaluated. The DOF of $\mathrm{L}_{27} \mathrm{OA}$ and two interaction is 26, minimum required DOF is 15 . So that, it is adequately enough for the problem under consideration. Two replicates were performed with experimental design. Table 4 shows the experimental design and results. "Smaller is better" for SR were compute [33]. Minitab-16 software has been used for analyzing the experimental results.

Smaller is better

$$
\left(\frac{S}{N}\right)_{S B}=-10 \log \left(\frac{1}{R} \sum_{j=1}^{R} y_{j}^{2}\right)
$$

Table 4. Experimental design and results.

\begin{tabular}{|c|c|c|c|c|c|c|c|c|c|c|}
\hline \multirow{2}{*}{ Trail } & \multicolumn{6}{|c|}{ Parameters } & \multicolumn{2}{|c|}{ SR Mean Value (micron) } & \multicolumn{2}{|c|}{ S/N Ratio } \\
\hline & A & B & C & D & $\mathbf{E}$ & $\mathbf{F}$ & PBPG & AHRG & PBPG & AHRG \\
\hline 1. & 1 & 1 & 1 & 1 & 1 & 1 & 1.57 & 1.29 & -3.917 & -2.211 \\
\hline 2. & 1 & 1 & 1 & 1 & 2 & 2 & 1.86 & 1.86 & -5.390 & -5.390 \\
\hline 3. & 1 & 1 & 1 & 1 & 3 & 3 & 1.42 & 1.42 & -3.045 & -3.045 \\
\hline 4. & 1 & 2 & 2 & 2 & 1 & 1 & 1.51 & 1.51 & -3.579 & -3.579 \\
\hline 5. & 1 & 2 & 2 & 2 & 2 & 2 & 1.68 & 1.68 & -4.506 & -4.506 \\
\hline 6. & 1 & 2 & 2 & 2 & 3 & 3 & 1.59 & 1.59 & -4.027 & -4.027 \\
\hline 7. & 1 & 3 & 3 & 3 & 1 & 1 & 1.33 & 1.33 & -2.477 & -2.477 \\
\hline 8. & 1 & 3 & 3 & 3 & 2 & 2 & 1.43 & 1.43 & -3.106 & -3.106 \\
\hline 9. & 1 & 3 & 3 & 3 & 3 & 3 & 1.29 & 1.29 & -2.211 & -2.211 \\
\hline 10. & 2 & 1 & 2 & 3 & 1 & 2 & 1.24 & 1.03 & -1.868 & -0.256 \\
\hline 11. & 2 & 1 & 2 & 3 & 2 & 3 & 1.34 & 1.34 & -2.542 & -2.542 \\
\hline 12. & 2 & 1 & 2 & 3 & 3 & 1 & 1.18 & 1.18 & -1.437 & -1.437 \\
\hline 13. & 2 & 2 & 3 & 1 & 1 & 2 & 1.46 & 1.46 & -3.287 & -3.287 \\
\hline 14. & 2 & 2 & 3 & 1 & 2 & 3 & 1.77 & 1.77 & -4.959 & -4.959 \\
\hline 15. & 2 & 2 & 3 & 1 & 3 & 1 & 1.32 & 1.32 & -2.411 & -2.411 \\
\hline 16. & 2 & 3 & 1 & 2 & 1 & 2 & 1.44 & 1.44 & -3.167 & -3.167 \\
\hline 17. & 2 & 3 & 1 & 2 & 2 & 3 & 1.59 & 1.59 & -4.027 & -4.027 \\
\hline 18. & 2 & 3 & 1 & 2 & 3 & 1 & 1.48 & 1.48 & -3.405 & -3.405 \\
\hline 19. & 3 & 1 & 3 & 2 & 1 & 3 & 1.12 & 0.93 & -0.984 & 0.6303 \\
\hline 20. & 3 & 1 & 3 & 2 & 2 & 1 & 1.27 & 1.27 & -2.076 & -2.076 \\
\hline 21. & 3 & 1 & 3 & 2 & 3 & 2 & 1.09 & 1.09 & -0.748 & -0.748 \\
\hline 22. & 3 & 2 & 1 & 3 & 1 & 3 & 1.14 & 1.14 & -1.138 & -1.138 \\
\hline 23. & 3 & 2 & 1 & 3 & 2 & 1 & 0.97 & 0.97 & 0.2645 & 0.2645 \\
\hline 24. & 3 & 2 & 1 & 3 & 3 & 2 & 1.02 & 1.02 & -0.172 & -0.172 \\
\hline 25. & 3 & 3 & 2 & 1 & 1 & 3 & 0.99 & 0.99 & 0.087 & 0.087 \\
\hline 26. & 3 & 3 & 2 & 1 & 2 & 1 & 1.06 & 1.06 & -0.506 & -0.502 \\
\hline 27. & 3 & 3 & 2 & 1 & 3 & 2 & 1.10 & 1.1 & -0.827 & -0.825 \\
\hline
\end{tabular}




\section{Results and Discussion}

During USM process, neither thermal nor residual stresses are generated on cutting zone. Surface roughness is the most important output response in USM, generally SR is influenced by grit size of abrasive $[1,3,4,7,12,47,48,50,63,69]$. SR is improved with appropriate selection of grit size $[7,18,39,48$, $57,69,72]$. Fine grit abrasive gives better SR [7, 9, 12, 19, 28, $3447,63]$. Higher rate of slurry flow and depth of cut attained better SR. At the bottom of the cavity, better quality of SR is found $[1,5,27,32,49,58]$. It is difficult to obtain the flat surface at the bottom of cavity, because of the uneven flow of slurry in the depth of cut $[14,50,59,64,68,78]$. For machining of glass, nimonic-80A tool material gives better response in term of SR and it have maximum resistant of tool wear property $[4,8,15,28,34,49,53,62]$. Maximum MRR of material produce poor SR and maximum tool wear $[14,58]$. Contamination, cavitation and debris blockage reduce the quality of SR $[4,19,52,60]$. Surface quality of cutting zone mainly affected by grit size and power rating parameters $[52$,
$61,63,64]$. Work material, grit size, concentration, tool and power rating are the controllable factor for better SR. Slurry concentration and abrasive grit size have the significant role in surface quality [1, 18, 24, 31, 48, 61]. Circulating high flow and fresh slurry will enhanced the surface quality [45, 61, 63]. SR decrease with decrease in power rating and grit size $[7,18$, $19,21,24,38,54]$. It also observed, temperature of slurry is most significant factor among all the considered input parameters $[15,29,37,49,61,62]$. Through analytical model is conclude that static load, tool vibration, abrasive and grit size increase the roughness of machined surface [4, 48, 61, 62]. Amplitude of vibration play the significant role in SR [14, 19, 38, 59, 62].

Smaller is better type response is preferred for SR. Therefore, maximum value of SR is consider for optimization. Figure 10 shows the optimum input parameters setting for SR; $40 \%$ concentration, $\mathrm{Al}_{2} \mathrm{O}_{3}+\mathrm{SiC}+\mathrm{B}_{4} \mathrm{C}$ abrasive, $20 \%$ power rating, 600 grit size, $1 \% \mathrm{HF}$ acid concentration and HSTS tool. $\mathrm{S} / \mathrm{N}$ ratio found to be high at these optimum level.

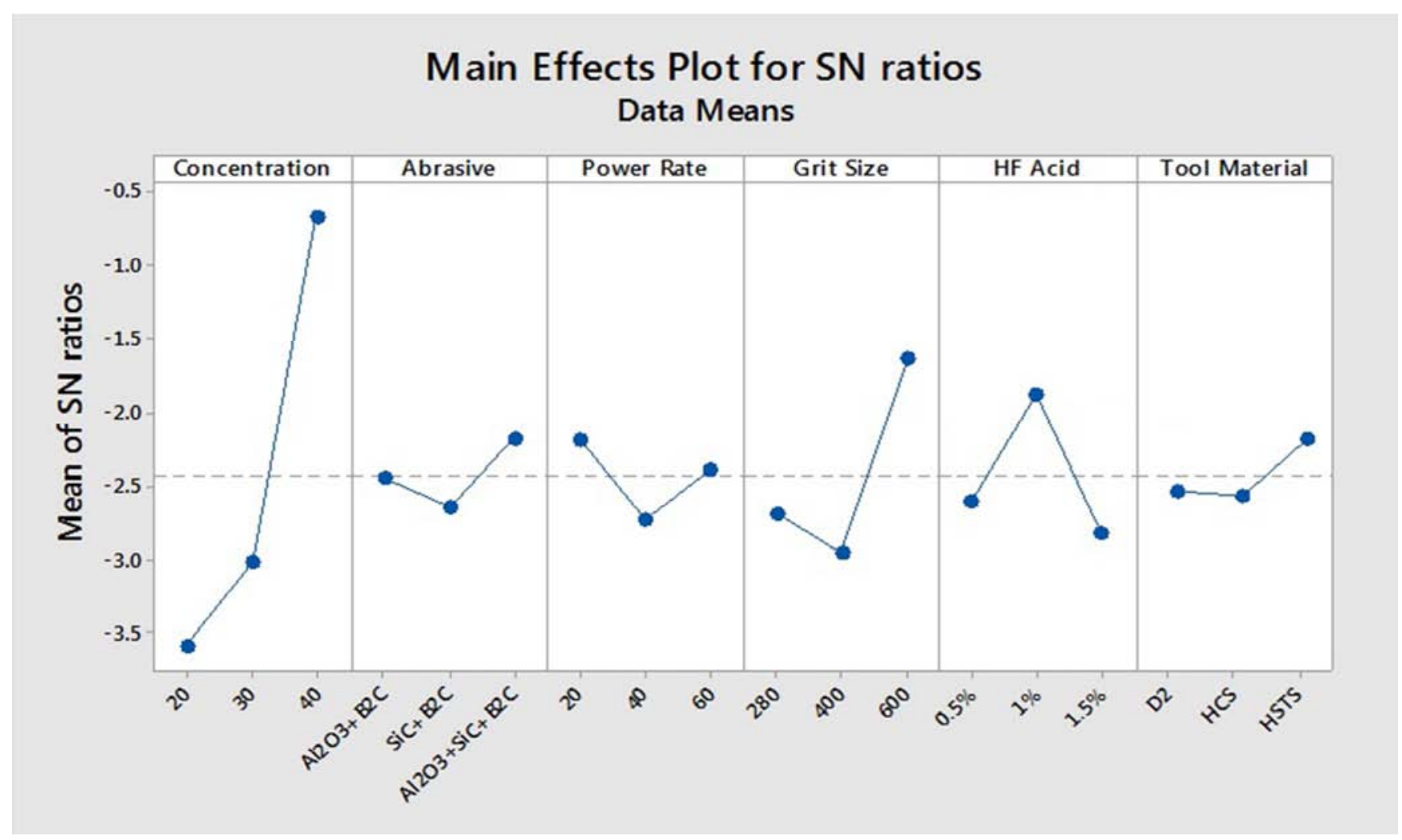

Figure 10. Mean effect plot for $S R$ in $P B P G$ (S/N ration), Optimized setting $A_{3} B_{3} C_{l} D_{3} E_{2} F_{3}$. 


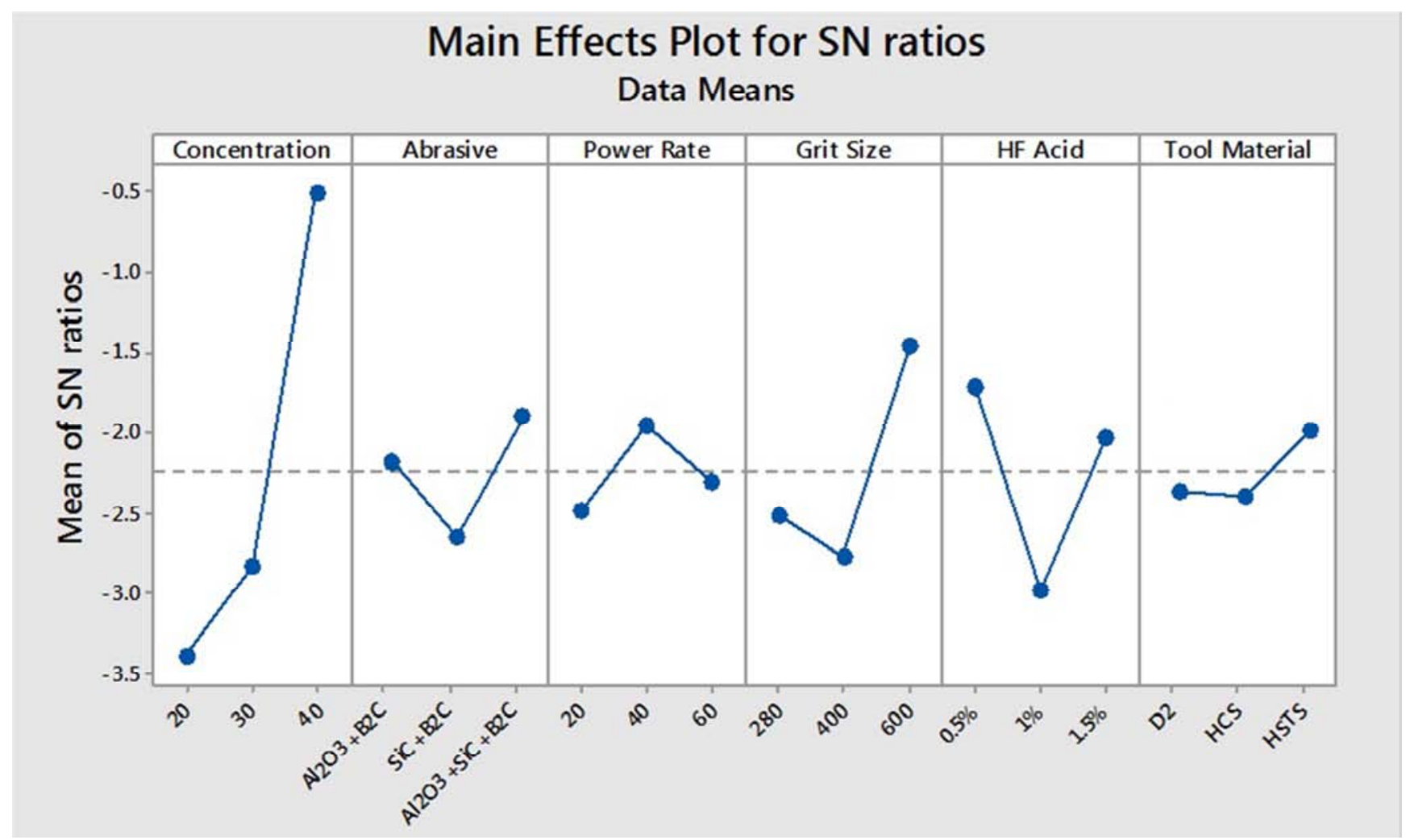

Figure 11. Mean effect plot for $S R$ in AHRG (S/N ration), Optimized setting $A_{3} B_{3} C_{2} D_{3} E_{1} F_{3}$.

Figure 11 shows the optimum parameter setting for SR are; $40 \%$ concentration, $\mathrm{Al}_{2} \mathrm{O}_{3}+\mathrm{B}_{4} \mathrm{C}$ abrasive, 40 power rating, 600 grit size, $0.5 \% \mathrm{HF}$ acid and HSTS tool.

\subsection{ANOVA Results}

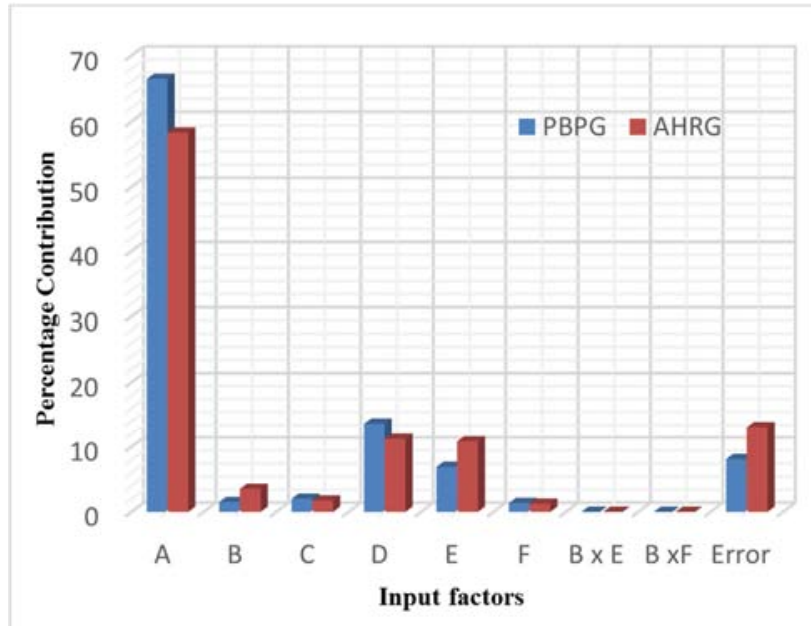

Figure 12. Percentage contribution of input variable for $S R$.

ANOVA technique was used on $\mathrm{S} / \mathrm{N}$ ratio of $\mathrm{PBPG}$ and AHRG, to evaluate the significance of the variables. Type of abrasive and grit size are main significant parameters for SR.
Interaction between $B \times E$ As per ANOVA test results for $\mathrm{S} / \mathrm{N}$ ration of $P B P G$ and $A H R G$, the input variable are sequenced in decreasing order of their significance, these variable are significant at $95 \%$ confidence level. For PBPG; concentration $(66.458 \%)$, grit size $(13.655 \%)$, HF acid (6.991\%), power rating $(2.039 \%)$, abrasive $(1.512 \%)$ and tool material (1.358\%). For AHRG; concentration (58.344\%), grit size (11.238\%), HF acid (10.824\%), abrasive (3.553\%), power rating $(1.713 \%)$ and tool material $(1.295 \%)$. Figure 12 shows the percentage contribution of input variable or SR.

\section{Surface Topography}

\subsection{Polycarbonate Bullet Proof Glass}

After machining, selected samples were examined through SEM (Model 435 VP, LEO) to investigate the SR. In USM, SR characteristics are generally affected by abrasive and grit size [16].

The USM machined sample of trail 14, input parameters are $30 \%$ concentration, $\mathrm{SiC}+\mathrm{B}_{2} \mathrm{C}$ mixed abrasive, 60 power rating, 280 grit size, $1 \%$ HF acid concentration and HSTS tool were used for machining. Figure 13 shows the machined sample and microstructure hole of trail 14 , in which excess material was removed at exit side. Figure 14 shows the microstructure of trail 14. Some fracture are tool place at cutting zone. 


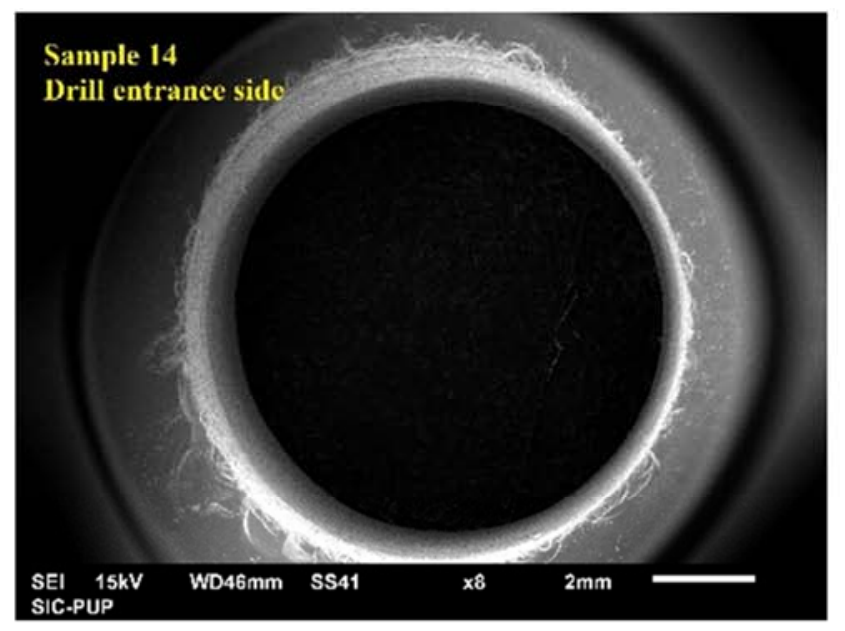

(a)

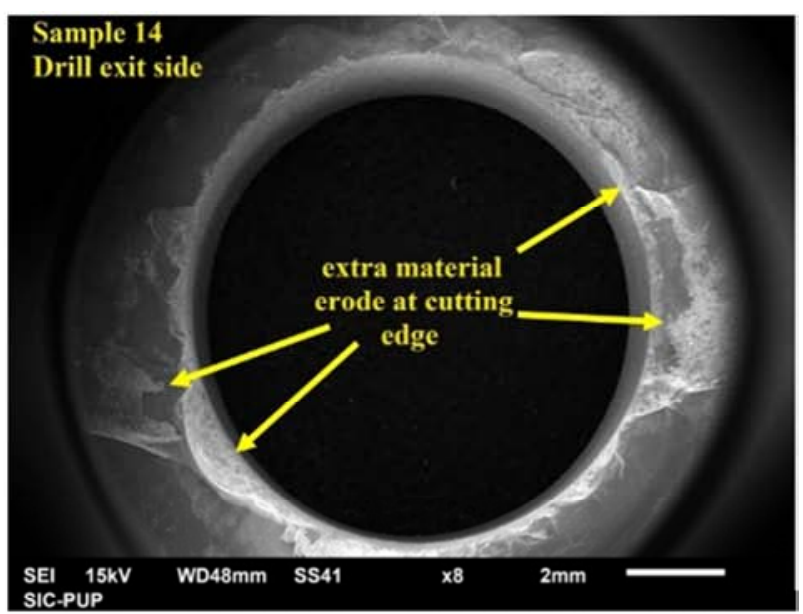

(b)

Figure 13. USM machined sample of trail 14 and microstructure of hole at $8 x$ (entrance and exit side).

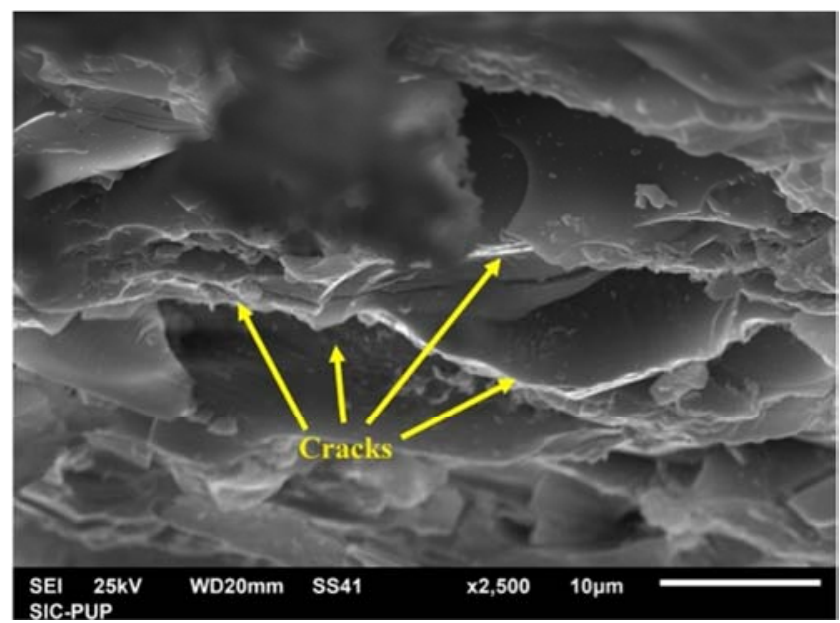

Figure 14. Microstructure of sample 14 at 2500x.

Figure 15 shoes the machined sample of experiment 26 and microstructure at $8 \mathrm{x}$ magnification. Sample was machined by 40 concentration, $\mathrm{Al}_{2} \mathrm{O}_{3}+\mathrm{SiC}+\mathrm{B}_{2} \mathrm{C}$ mixed abrasive, 40 power rating, 280 coarse grit, $1 \% \mathrm{HF}$ acid concentration and $\mathrm{D} 2$ steel

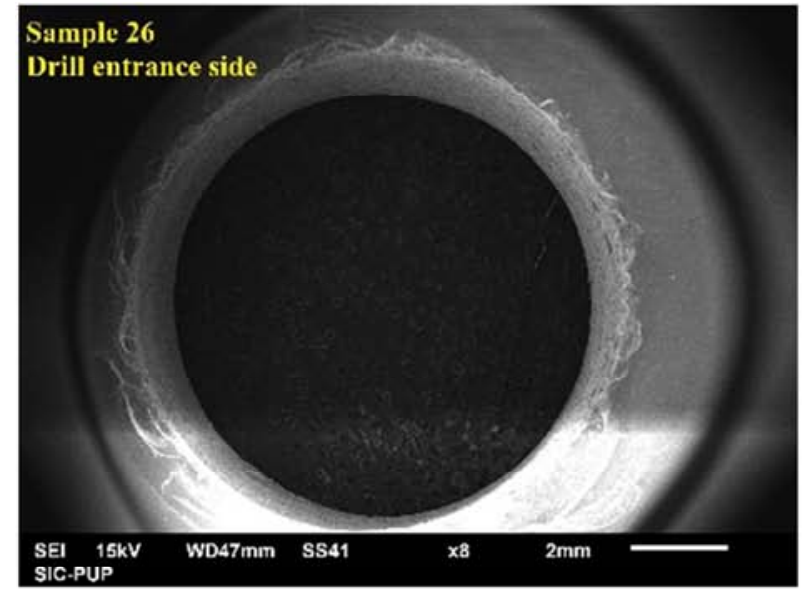

(a) tool. Almost straight cylindrical profile has been observed and exit side have some uneven erosion area, due to non-uniform tool wear. Figure 16 shows the microstructure of sample 26 at 2500x, some major cracks on machined surface are found.

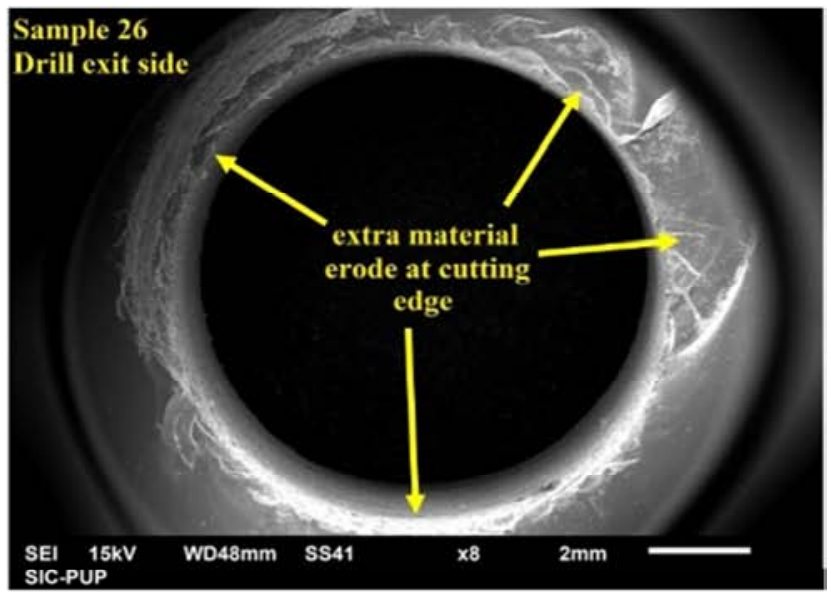

(b)

Figure 15. USM machined sample of trail 26 and microstructure of hole at $8 x$ (entrance and exit side). 


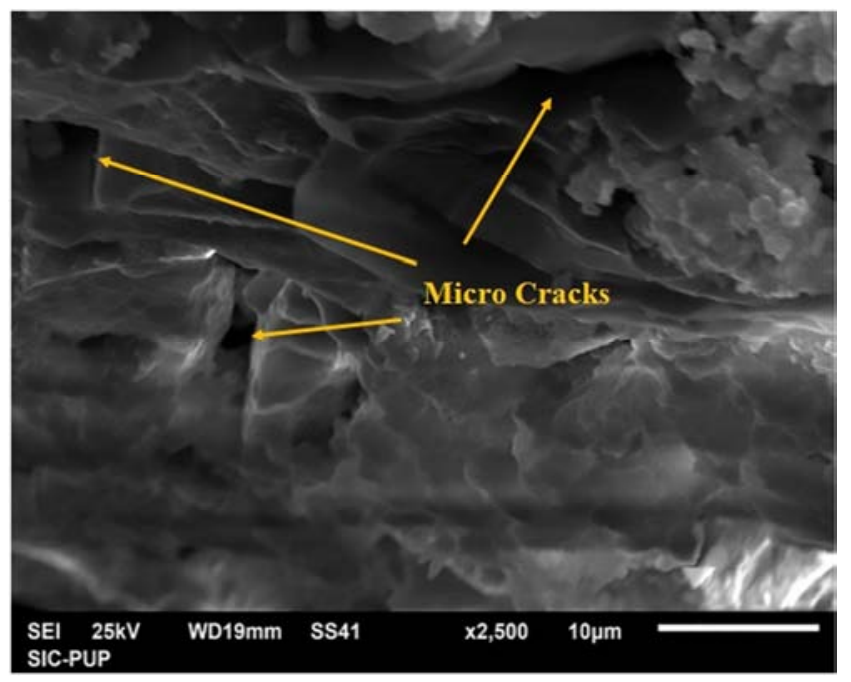

Figure 16. Microstructure of sample 26 at $2500 x$.

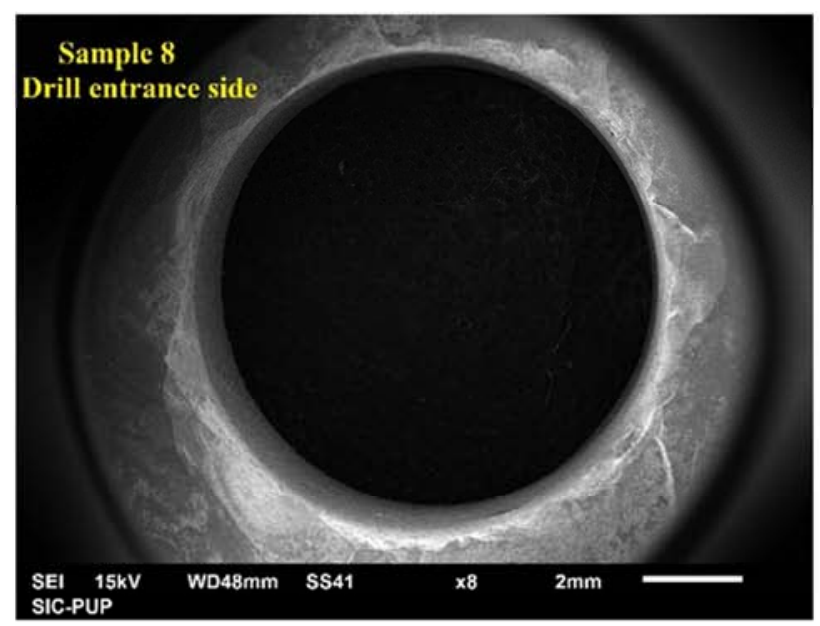

(a)

\subsection{Acrylic Heat Resistant Glass}

After machining, selected samples were examined through SEM (Model 435 VP, LEO) to investigate the SR. In USM, SR characteristics are generally affected by abrasive and grit size [16]. Figure 17 shoes the machined (AHRG) sample of experiment 8 and microstructure at $8 \mathrm{x}$ magnification. Sample was machined by $20 \%$ concentration, $\mathrm{Al}_{2} \mathrm{O}_{3}+\mathrm{SiC}+\mathrm{B}_{2} \mathrm{C}$ mixed abrasive, 60 power rating, 600 coarse grit, $1 \% \mathrm{HF}$ acid concentration and HCS tool. Almost straight cylindrical profile has been observed and exit side have some uneven erosion area, due to non-uniform tool wear. Figure 18 shows the microstructure of sample 08 at $2500 x$, some major cracks on machined surface are found.

The USM machined sample of trail 16, input parameters are $30 \%$ concentration, $\mathrm{Al}_{2} \mathrm{O}_{3}+\mathrm{SiC}+\mathrm{B}_{2} \mathrm{C}$ mixed abrasive, 20 power rating, 400 grit size, $0.5 \% \mathrm{HF}$ acid concentration and $\mathrm{HCS}$ tool were used for machining. Figure 21 shows the machined sample and microstructure hole of trail 19 , in which excess material was removed at exit side. Figure 20 shows the microstructure of trail 16. Some fracture are tool place at cutting zone.

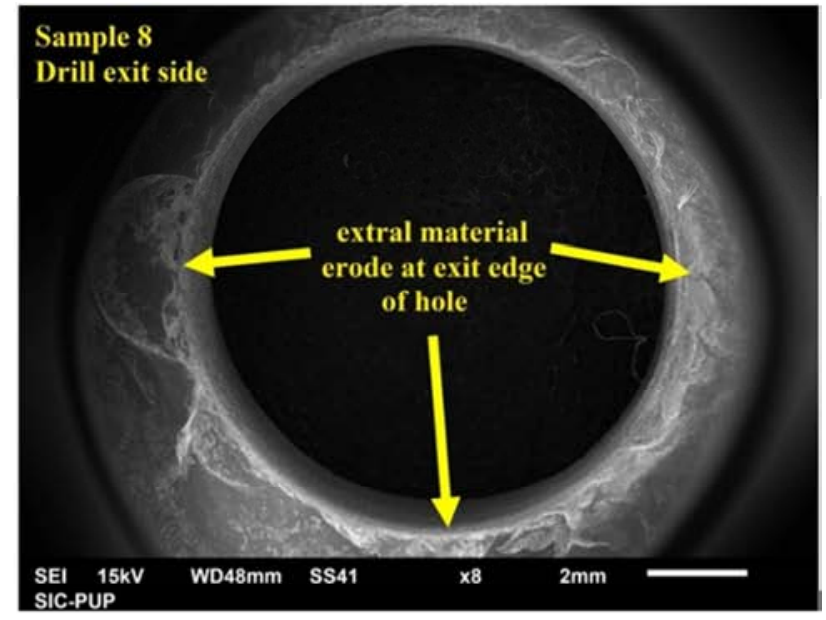

(b)

Figure 17. USM machined sample of trail 26 and microstructure of hole at $8 x$ (entrance and exit side).

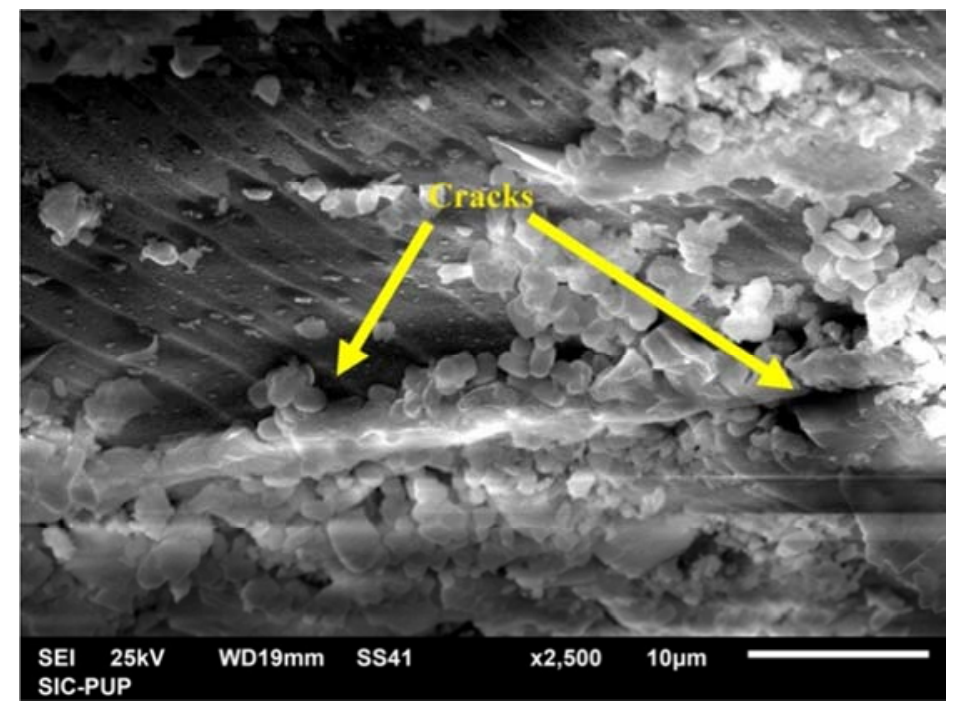

Figure 18. Microstructure of sample 26 at $2500 x$. 


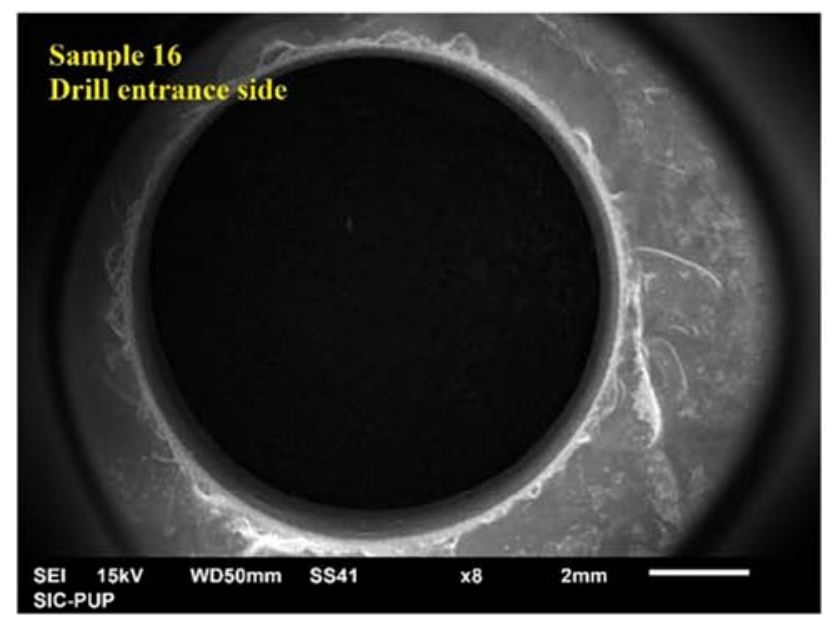

(a)

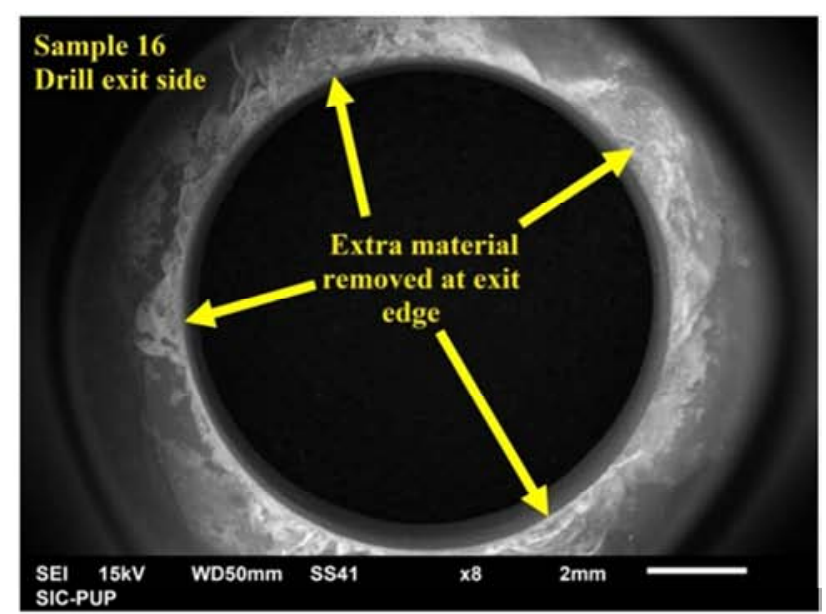

(b)

Figure 19. USM machined sample of trail 26 and microstructure of hole at $8 x$ (entrance and exit side).

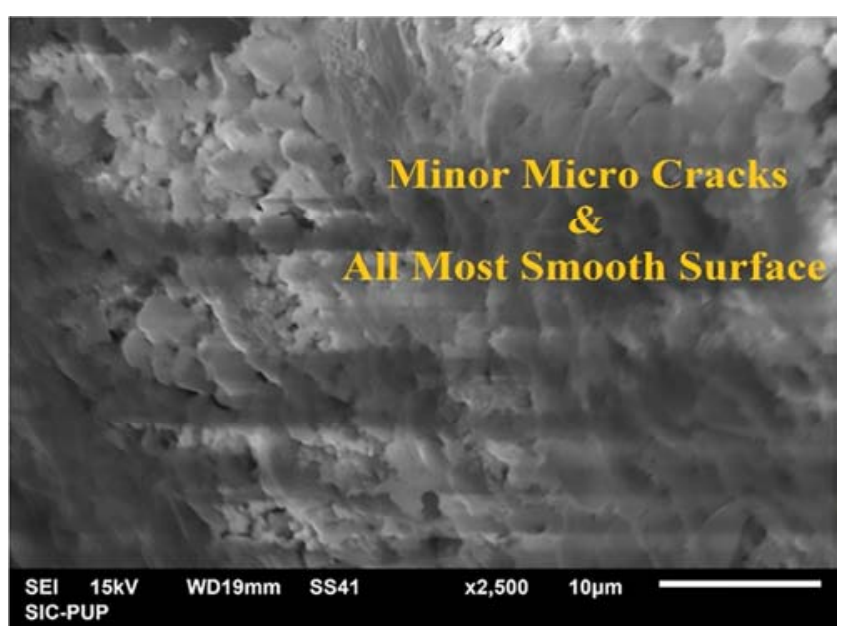

Figure 20. Microstructure of sample 26 at $2500 x$.

\section{Multi-Response Optimization}

In USM, SR is the most significant output responses. Under particular setting of machining, minimum SR cannot be achieved. For commercial utilization, it is essential to optimize the multiple responses concurrently. In this regards, GRA approach is employed for multi response optimization.

\subsection{Grey Relational Method}

GRA is an effective method, it is used to solve the complicated inter-relationship of data. The main advantages of GRA methods are; easy to apply, gives accurate results, simple to computation. For commercial manufacturing problems, GRA method gives best decisions [87, 88, 89, 91, 93, 94, 95, 96].

In GRA approach, the experimental results data is normalized and fit in a range of 0 to 1 . GRC is calculate through normalized data, it represent relationship between required and actual experimental results. For SR "Lower-the-best" type response is considered.

Lower-the-best response for SR has been scaled by Eq. 2
$[90,91,92] ;$

$$
\chi_{Z J V}^{*}=\frac{\operatorname{Min} \cdot \chi_{Z J i}}{\chi_{J i}}
$$

Where; $\operatorname{Min} \chi_{Z_{J i}}=\operatorname{Min}\left\{Z_{1 \mathrm{Ji}}, Z_{2 \mathrm{Ji}}, \ldots \ldots, \mathrm{Z}_{\mathrm{MJi}}\right\}$ and $\operatorname{Max} \chi_{Z J i}=$ $\operatorname{Max}\left\{Z_{1 \mathrm{Ji}}, \mathrm{Z}_{2 \mathrm{Ji}}, \ldots \ldots, \mathrm{Z}_{\mathrm{MJi}}\right\}$

The GRC $\left(\zeta_{Z J}\right)$ for $\mathrm{J}^{\text {th }}$ response in $Z^{\text {th }}$ trail can be calculated by Eq. 3 [90, 91, 92];

$$
\zeta_{Z J}=\frac{\Delta_{J}^{M i n}+\xi \Delta_{J}^{M a x}}{\Delta_{Z J}+\xi \Delta_{J}^{M a x}}
$$

Where, $\Delta_{Z J}=\left|1-\chi_{Z J V}\right|, \Delta_{J}^{\operatorname{Min}}=\operatorname{Min}\left\{\Delta_{1 J}, \Delta_{2 J}, \ldots ., \Delta_{M J}\right\}$, $\Delta_{J}^{\operatorname{Max}}=\operatorname{Max}\left\{\Delta_{1 J}, \Delta_{2 J}, \ldots, \Delta_{M J}\right\}$ and $\xi$ is stated as distinguishing coefficient $((\xi \in[0,1])$, and usually its value is set as 0.5 . It is used as a modification factors to the range of GRC. The GRG is calculated by equation 5 [90, 91 92], considering the equal weightage for SR. Table 5 shows the GRA calculation data. The mean of output response or GRG for each level of input factors is shown in table 5 .

$$
G R G_{Z}=\sum_{J=1}^{n} W_{J} \times \zeta_{Z J}
$$

Figure 21 shows the mean effect plot for GRG. Higher value of GRG reflects the closeness to the idealistic characteristics. The optimum level of input parameters corresponding to maximum average GRG are $\mathrm{A}_{3} \mathrm{~B}_{3} \mathrm{C}_{2} \mathrm{D}_{3} \mathrm{E}_{1} \mathrm{~F}_{3}$. The optimum parameter setting is; $40 \%$ concentration, $\mathrm{Al}_{2} \mathrm{O}_{3}+\mathrm{SiC}+\mathrm{B}_{4} \mathrm{C}$ mixed abrasive, $40 \%$ power rating, 600 grit size, $1 \%$ HF acid and HSTS tool. The confirmation experiment with optimum setting was also performed. The experimental value of PBPG SR and AHRG SR at optimum setting were found to be 0.71 micron and 0.66 micron respectively. 


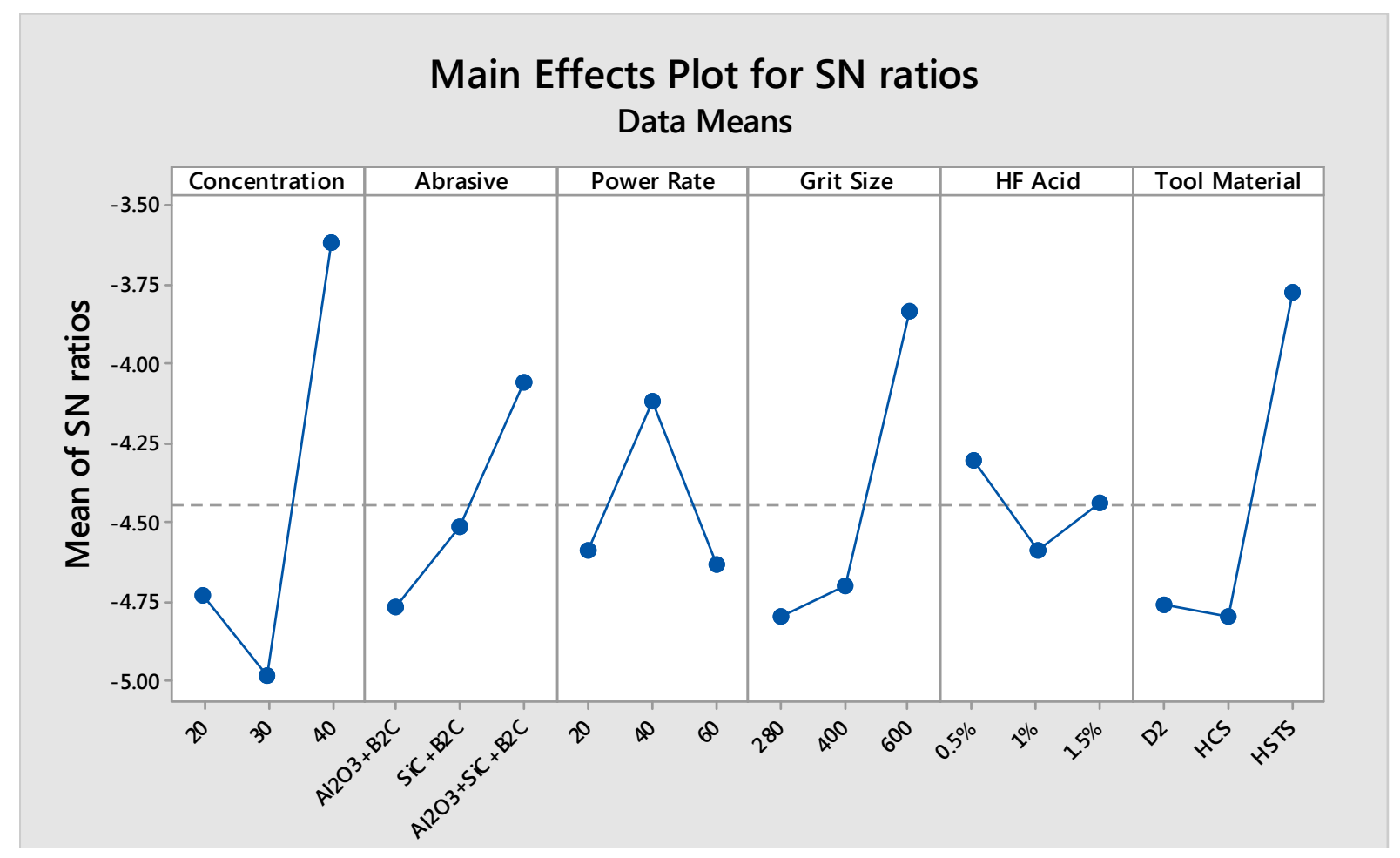

Figure 21. Mean effect plot of GRG, Optimum setting $A_{3} B_{3} C_{2} D_{3} E_{1} F_{3}$.

Table 5. Computed data for GRA.

\begin{tabular}{|c|c|c|c|c|c|}
\hline Trail & $\begin{array}{l}\text { Normalized Value } \\
\text { PBPG }\end{array}$ & AHRG & $\begin{array}{l}\text { GRC } \\
\text { PBPG }\end{array}$ & AHRG & GRG \\
\hline 1 & 0.32584 & 0.6129 & 0.4258 & 0.3870 & 0.4942 \\
\hline 2 & 0 & 0 & 0.3333 & 1 & 0.4752 \\
\hline 3 & 0.4943 & 0.4731 & 0.4972 & 0.5268 & 0.6267 \\
\hline 4 & 0.3932 & 0.3763 & 0.4517 & 0.6236 & 0.5639 \\
\hline 5 & 0.2022 & 0.1935 & 0.3852 & 0.8064 & 0.5712 \\
\hline 6 & 0.3033 & 0.2903 & 0.4174 & 0.7096 & 0.6074 \\
\hline 7 & 0.5955 & 0.5698 & 0.5527 & 0.4301 & 0.6540 \\
\hline 8 & 0.4831 & 0.4623 & 0.4917 & 0.5376 & 0.5702 \\
\hline 9 & 0.6404 & 0.6129 & 0.5816 & 0.3870 & 0.6923 \\
\hline 10 & 0.6966 & 0.8924 & 0.6223 & 0.1075 & 0.5997 \\
\hline 11 & 0.5842 & 0.559 & 0.5460 & 0.4406 & 0.6362 \\
\hline 12 & 0.7640 & 0.7311 & 0.6793 & 0.2688 & 0.5793 \\
\hline 13 & 0.4494 & 0.4301 & 0.4759 & 0.5698 & 0.5191 \\
\hline 14 & 0.1011 & 0.0967 & 0.3574 & 0.9032 & 0.5504 \\
\hline 15 & 0.6067 & 0.5806 & 0.5597 & 0.4193 & 0.5076 \\
\hline 16 & 0.4719 & 0.4516 & 0.4863 & 0.5483 & 0.5708 \\
\hline 17 & 0.3033 & 0.2903 & 0.4178 & 0.7096 & 0.6077 \\
\hline 18 & 0.4269 & 0.4086 & 0.4659 & 0.5913 & 0.5133 \\
\hline 19 & 0.8314 & 1 & 0.7479 & 0 & 0.6691 \\
\hline 20 & 0.6629 & 0.6344 & 0.5973 & 0.3655 & 0.5320 \\
\hline 21 & 0.8651 & 0.8279 & 0.7876 & 0.1720 & 0.6177 \\
\hline 22 & 0.8089 & 0.7741 & 0.7235 & 0.2258 & 0.7094 \\
\hline 23 & 1 & 0.9569 & 1 & 0.0430 & 0.6814 \\
\hline 24 & 0.9438 & 0.9032 & 0.8989 & 0.0967 & 0.6798 \\
\hline 25 & 0.9775 & 0.9354 & 0.9569 & 0.0645 & 0.7495 \\
\hline 26 & 0.8988 & 0.8602 & 0.8317 & 0.1397 & 0.7217 \\
\hline 27 & 0.8539 & 0.8172 & 0.7739 & 0.1827 & 0.5988 \\
\hline
\end{tabular}

Table 6. Response table for mean of the $G R G$.

\begin{tabular}{lllllll}
\hline Level & Concentration & Abrasive & Power rating & Grit size & HF acid & Tool material \\
\hline 1 & 0.583 & 0.581 & 0.595 & 0.582 & $0.614^{*}$ & 0.583 \\
2 & 0.565 & 0.599 & $0.625^{*}$ & 0.583 & 0.594 & 0.578 \\
3 & $0.662^{*}$ & $0.631^{*}$ & 0.590 & $0.644^{*}$ & 0.602 & $0.649^{*}$ \\
\hline
\end{tabular}


Table 7. Predicted and confirmation results at optimum setting.

\begin{tabular}{lllll}
\hline $\begin{array}{l}\text { Output } \\
\text { response }\end{array}$ & Predicted Value PBPG & Predicted Value AHRG & Confirmation results PBPG \\
\hline SR & $\mathbf{A}_{\mathbf{3}} \mathbf{B}_{\mathbf{3}} \mathbf{C}_{\mathbf{2}} \mathbf{D}_{\mathbf{3}} \mathbf{E}_{\mathbf{1}} \mathbf{F}_{\mathbf{3}}$ & $\mathbf{A}_{\mathbf{3}} \mathbf{B}_{\mathbf{3}} \mathbf{C}_{\mathbf{1}} \mathbf{D}_{\mathbf{3}} \mathbf{E}_{\mathbf{2}} \mathbf{F}_{\mathbf{3}}$ & $\mathbf{A}_{\mathbf{3}} \mathbf{B}_{\mathbf{3}} \mathbf{C}_{\mathbf{2}} \mathbf{D}_{\mathbf{3}} \mathbf{E}_{\mathbf{1}} \mathbf{F}_{\mathbf{3}}$ & $\mathbf{A}_{\mathbf{3}} \mathbf{B}_{\mathbf{3}} \mathbf{C}_{2} \mathbf{D}_{\mathbf{3}} \mathbf{E}_{\mathbf{1}} \mathbf{F}_{\mathbf{3}}$ \\
\hline
\end{tabular}

Table 8. Summary of selected research papers on USM of glass material.

\begin{tabular}{|c|c|c|c|c|c|}
\hline Sr. No & Author (s) & Work material & Input factors & $\begin{array}{l}\text { Output factors and } \\
\text { Optimized Results }\end{array}$ & Results or conclusion \\
\hline 1. & $\begin{array}{l}\text { K. Singh et al. } \\
2016[53]\end{array}$ & Glass & $\begin{array}{l}\text { Abrasive }\left(\mathrm{Al}_{2} \mathrm{O}_{3}, \mathrm{SiC}, \text { Mixture }\right) \\
\text { Power rating } 60 \\
\text { Grit } 280 \\
\text { Concentration } 30 \% \\
\mathrm{HF} \text { acid } 2 \%\end{array}$ & $\begin{array}{l}\mathrm{MRR}=21 \mathrm{~mm}^{3} / \mathrm{min} \\
\mathrm{TWR}=1.02 \mathrm{~mm}^{3} / \mathrm{min} \\
\mathrm{SR}=1.02 \mathrm{micron}\end{array}$ & $\begin{array}{l}\text { CUSM gives more MRR as compare to } \\
\text { USM. Better SR is achieved in CUSM. } \\
\text { High concentration of HF acid increase the } \\
\text { TWR. }\end{array}$ \\
\hline 2. & $\begin{array}{l}\text { K. Singh et al. } \\
2015[51]\end{array}$ & Glass & $\begin{array}{l}\text { Abrasive }\left(\mathrm{Al}_{2} \mathrm{O}_{3}, \mathrm{SiC}, \text { Mixture }\right) \\
\text { Power rating } 40 \text { Grit } 400 \\
\text { Concentration } 30 \% \\
\mathrm{HF} \text { acid } 2 \%\end{array}$ & $\begin{array}{l}\mathrm{SR}=0.98 \mathrm{micron} \\
\mathrm{MRR}=28 \mathrm{~mm}^{3} / \mathrm{min}\end{array}$ & $\begin{array}{l}\text { HF acid in Alumina, SiC and Alumina }+ \\
\text { SiC abrasive improve the SR } 33.86 \% \text {, } \\
22.84 \% \text { and } 55.43 \% \text {, Similarly Improve } \\
\text { MRR } 31.85 \%, 40.82 \% \text { and } 64.08 \% \\
\text { respectively. }\end{array}$ \\
\hline 3. & $\begin{array}{l}\text { J. Kumar and } \\
\text { J. S Khamba } \\
2009[66]\end{array}$ & $\begin{array}{l}\text { Carbide glass, } \\
\mathrm{HCS}, \mathrm{HSS}, \mathrm{Al} \text { and } \\
\mathrm{Ti}\end{array}$ & $\begin{array}{l}\text { Work material (HCS, HSS, Al, } \\
\text { Titanium, Carbide, Glass) } \\
\text { Tool material (HCS, Titanium, } \\
\text { Titanium alloy) Abrasive } \\
\left(\mathrm{Al}_{2} \mathrm{O}_{3}, \mathrm{SiC}, \mathrm{B}_{4} \mathrm{C}\right) \text { Grit size } \\
(220,320,500) \text { Tool geometry } \\
\text { (Solid } 8 \mathrm{~mm} \text {, Solid } 4 \mathrm{~mm} \text {, } \\
\text { Hollow 8/4) }\end{array}$ & $\begin{array}{l}\mathrm{MRR}=21.07 \\
\mathrm{~mm}^{3} / \mathrm{min} \\
\mathrm{TWR}=1.9 \mathrm{~mm}^{3} / \mathrm{min}\end{array}$ & $\begin{array}{l}\text { For tool wear, tool geometry } 35.37 \% \text {, grit } \\
\text { size } 20.12 \% \text { and abrasive } 19.95 \% \text { were the } \\
\text { significant factor. For material removal; } \\
\text { work material } 79 \% \text {, tool geometry } 10.86 \% \\
\text { and grit size } 5.50 \% \text { significant factor. For } \\
\text { TWR; work material was most significant } \\
\text { factor. }\end{array}$ \\
\hline 4. & $\begin{array}{l}\text { J. P. Choi et } \\
\text { al. } 2007[21]\end{array}$ & Glass & $\begin{array}{l}\text { Abrasive }=\mathrm{SiC} \\
\text { Static load }=0.1 \text { gf } \\
\mathrm{HF} \text { acid }=3-5 \% \text {, grit, }\end{array}$ & $\begin{array}{l}\text { MRR increased } 200 \% \text {, } \\
\text { SR improved } 40 \% \text {, }\end{array}$ & $\begin{array}{l}\text { HF acid improve the MRR upto } 200 \% \text {, } \\
\text { CUSM gives better SR as compare to USM } \\
\text { and static load decreased dramatically. }\end{array}$ \\
\hline 5. & $\begin{array}{l}\text { P. L. Guzzo et } \\
\text { al. } 2003 \text { [17] }\end{array}$ & $\begin{array}{l}\text { Soda lime glass, } \\
\text { Alumina, } \\
\text { Zirconia, LiF } \\
\text { Quartz and Ferrite }\end{array}$ & $\begin{array}{l}\text { Thickness of material }(0.5 \text { to } \\
1.75 \mathrm{~mm}) \\
\text { Grit size }(6,15,25,35 \text { and } 50 \\
\mu \mathrm{m}) \\
\text { Abrasive }\left(\mathrm{Al}_{2} \mathrm{O}_{3} \mathrm{SiC}, \mathrm{B}_{4} \mathrm{C}\right)\end{array}$ & $\begin{array}{l}\mathrm{MRR}=3.4 \mu \mathrm{m} / \mathrm{s} \\
\mathrm{SR}=1.2 \text { micron }\end{array}$ & $\begin{array}{l}\text { MRR is inversely proportional to depth of } \\
\text { cut in alumina, zircona and quartz material, } \\
\text { in other material it may be constant. MRR } \\
\text { and SR dependent on H/E ratio. }\end{array}$ \\
\hline 6. & $\begin{array}{l}\text { M. } \\
\text { Komaraiah } \\
\text { and P. } \\
\text { Narasimha } \\
1993[18]\end{array}$ & Glass & $\begin{array}{l}\text { Tool material and tool motion } \\
\text { (stationary and rotary) }\end{array}$ & $\begin{array}{l}\mathrm{MRR}=1.2 \log \mathrm{MRR} \\
\left(\mathrm{mm}^{3} / \mathrm{min}\right) \\
\mathrm{TWR}=0.6 \log \mathrm{TWR} \\
\left(\mathrm{mm}^{3} / \mathrm{min}\right)\end{array}$ & $\begin{array}{l}\text { Decreasing order of tool performance } \\
\text { according to TWR; nimonic- } 80 \mathrm{~A}> \\
\text { thoriated tungsten }>\text { sliver steel }>\text { maraging } \\
\text { steel }>\text { stainless steel }>\text { titanium }>\text { mild } \\
\text { steel. Higher MRR gives high TWR. }\end{array}$ \\
\hline 7. & $\begin{array}{l}\text { M. } \\
\text { Komaraiah et } \\
\text { al. } 1988[33]\end{array}$ & $\begin{array}{l}\text { Glass, Ferrite, } \\
\text { Porcelain, alumina } \\
\text { and carbide }\end{array}$ & Work material and tool material & $\begin{array}{l}\mathrm{MRR}=\mathrm{mm}^{3} / \mathrm{min} \\
11.48 \\
\mathrm{SR}=1.8 \mathrm{Micron} \\
\text { Out of roundness } \\
=0.085 \mathrm{~mm}\end{array}$ & $\begin{array}{l}\text { Higher } \mathrm{H} / \mathrm{E} \text { ratio material gives higher } \\
\text { MRR and higher out-of roundness. RUSM } \\
\text { gives better results as compare to simple } \\
\text { USM. }\end{array}$ \\
\hline 8. & $\begin{array}{l}\text { M. Adithan } \\
\text { and V. C. } \\
\text { Venkatesh } \\
1976[57]\end{array}$ & Glass & $\begin{array}{l}\text { Tool materal }=\text { mild steel, silver } \\
\text { steel, tungsten carbide and } \\
\text { Stainless steel } \\
\text { Abrasive }=\mathrm{SiC} \text { and } \mathrm{B}_{4} \mathrm{C} \\
\text { Grit Size }=280 \text { and } 600 \\
\text { Static load }\end{array}$ & $\begin{array}{l}\text { TWR }=0.84 \mathrm{~mm}^{3} / \mathrm{min} \\
\text { Out of roundness } \\
=0.092 \mathrm{~mm}\end{array}$ & $\begin{array}{l}\text { Oversize of hole and conicity effects are } \\
\text { increased with higher static load and } \\
\text { machining time. It also depends upon the } \\
\text { brittle fracture characteristics and grain } \\
\text { structure of work material. }\end{array}$ \\
\hline 9. & $\begin{array}{l}\text { M. Adithan } \\
1974[37]\end{array}$ & $\begin{array}{l}\text { Glass and } \\
\text { porcelain }\end{array}$ & $\begin{array}{l}\text { Work material }=\text { glass and } \\
\text { porcelain } \\
\text { Thickness of material }=0.50 \text { to } \\
2.25 \mathrm{~mm} \\
\text { Tool material = Mild stel, Silver } \\
\text { steel, stainless steel and } \\
\text { tungsten carbide } \\
\text { Abrasive }=\mathrm{Al}_{2} \mathrm{O}_{3}, \mathrm{SiC} \text { and } \mathrm{B}_{4} \mathrm{C} \\
\text { Grit } \mathrm{Size}=280 \text { and } 600\end{array}$ & $\begin{array}{l}\mathrm{MRR}=1.54 \mathrm{~mm}^{3} / \mathrm{min} \\
\mathrm{TWR}=0.2 \mathrm{~mm}^{3} / \mathrm{min}\end{array}$ & $\begin{array}{l}\text { Tool wear rate increase with increase in } \\
\text { static load. } \mathrm{B}_{4} \mathrm{C} \text { abrasive gives more TWR } \\
\text { as compare to } \mathrm{Al}_{2} \mathrm{O}_{3} \text { and } \mathrm{SiC}\end{array}$ \\
\hline 10. & $\begin{array}{l}\text { A. Schorderet } \\
\text { et at } 2013[67]\end{array}$ & Glass & $\begin{array}{l}\text { Abrasive }=\mathrm{B}_{4} \mathrm{C} \\
\text { Concentration } 10 \% \\
\text { Grit size }=5 \mu \mathrm{m} \\
\text { Tool Material = WC, HSS }\end{array}$ & $\begin{array}{l}\operatorname{MRR}(\mathrm{WC})=0.0149 \\
\mathrm{~mm}^{3} / \mathrm{min} \\
\left.\mathrm{TWR}_{(\mathrm{WC}}\right)=5.3 \mu \mathrm{m} / \mathrm{s}\end{array}$ & $\begin{array}{l}\text { Twisted gouges drill gives better result as } \\
\text { compare to plain drill. } \\
\text { High flow rate remove the debris at } \\
\text { machining zone. }\end{array}$ \\
\hline
\end{tabular}




\section{Conclusion}

Surface roughness is generally effected by abrasive type, grit size and $\mathrm{HF}$ concentration. Harder abrasive like $\mathrm{SiC}$ gives the poor surface roughness. Cores grit size abrasive improve material removal rate, but decrease surface smoothness. In other hand, fine grit size abrasive gives fine surface finish, but produce low material removal rate. HF acid is the most significant parameter in machining of glass, polycarbonate and acrylic materials. It reduce the crack formation at cutting zone.

From mathematical modeling, it observed that harder abrasive particles produce indent in material as well as tool. So that material removal rate is directly proportional to tool wear rate. Higher material removal rate encourage higher tool wear rate and gives poor surface finish.

MRR and TWR is generally effected by layers of glass and polycarbonate materials. Because, indentation is proportional to fracture and hardness of material. High hardness material gives better MRR. $\mathrm{Al}_{2} \mathrm{O}_{3}+\mathrm{SiC}+\mathrm{B}_{4} \mathrm{C}$ mixed abrasive slurry and high power rating boost the MRR, results in a corresponding high wear occur at tool. Grit size have significant role in machining, higher grit size gives better MRR. But, it also encourage the tool wear. Fine grit produce low TWR, high SR and lower MRR. HF acid enhance the MRR of glass material. High concentration of $\mathrm{HF}$ acid is harmful for user and it also damage the machine and equipment.

Harder tool gives lower TWR, high speed tool steel is best for the machining of glass and polycarbonate material. It produce lower tool wear and higher material removal rate. Optimum setting for minimum SR (in PBPG and AHRG) was $40 \%$ concentration, $\mathrm{Al}_{2} \mathrm{O}_{3}+\mathrm{SiC}+\mathrm{B}_{4} \mathrm{C}$ mixed abrasive, $20 \%$ power rating, 600 grit size, $1 \% \mathrm{HF}$ acid and HSTS tool. For multi-response optimization, the experiment setting were; $40 \%$ concentration, $\mathrm{Al}_{2} \mathrm{O}_{3}+\mathrm{SiC}+\mathrm{B}_{4} \mathrm{C}$ mixed abrasive, $40 \%$ power rating, 600 grit size, $0.5 \% \mathrm{HF}$ acid and HSTS tool. Through GRA approach, surface finish improved by $40 \%$ and $48 \%$ in polycarbonate bullet proof (UL-752) and acrylic heat resistant (BS-476) glass respectively.

\section{Abbreviation}

$\begin{array}{ll}\text { CUSM } & \text { Chemical assisted ultrasonic machining } \\ \text { PBPG } & \text { Polycarbonate bullet proof (UL-752) glass } \\ \text { AHRG } & \text { Acrylic heat resistant (BS-476) glass } \\ \text { HF } & \text { Hydrofluoric } \\ \text { MRR } & \text { Material removal rate } \\ \text { TWR } & \text { Tool wear rate } \\ \text { SR } & \text { Surface roughness } \\ \text { DOE } & \text { Design of experiment } \\ \text { DOF } & \text { Degree of freedom } \\ \text { OA } & \text { Orthogonal array } \\ \text { GRA } & \text { Grey relation analysis } \\ \text { GRC } & \text { Grey relation coefficient } \\ \text { GRG } & \text { Grey relation grade } \\ \text { F } & \text { Fisher's test } \\ \text { S/N } & \text { Signal to noise ratio }\end{array}$

$\begin{array}{ll}\text { ANOVA } & \text { Analysis of variance } \\ \text { SEM } & \text { Scanning electron microscope }\end{array}$

\section{References}

[1] Dvivedi, A.; Kumar, P. Surface quality evaluation in ultrasonic drilling through the taguchi technique. International Journal of Advanced Manufacturing Technology 2007; 34 (1-2): 131-140. DOI: $10.1007 / \mathrm{s} 00170-006-0586-3$.

[2] Gauri, S. K.; Chakravorty, R.; Chakraborty, S. Optimization of correlated multiple responses of ultrasonic machining (USM) process. International Journal of Advanced Manufacturing Technology 2011; 53: 1115-1127. DOI: 10.1007/s00170-010-2905-y.

[3] Gilmore, R. Ultrasonic machining- a case study. Journal of Materials Processing Technology 1991; 28 (1-2): 139-148. http://dx.doi.org/10.1016/0924-0136(91)90213-X

[4] Ghahramani, B.; Wang, Z. Y. Precision ultrasonic machining process: A case study of stress analysis of ceramic $\left(\mathrm{Al}_{2} \mathrm{O}_{3}\right)$. International Journal of Machine Tools and Manufacture 2001; 41 (8): 1189-1208.

http://dx.doi.org/10.1016/S0890-6955(01)00011-6

[5] Goetze, D. Effect of vibration amplitude, frequency, and composition of the abrasive slurry on the rate of ultrasonic machining in ketos tool steel. Journal of Acoustical Society of America 1956; 28 (6): 1033-1045. doi: http://dx.doi.org/10.1121/1.1908545

[6] Kennedy, D. C.; Grieve R. J. Ultrasonic machining- a review. The Production Engineer 1975; 54 (9): 481-486. DOI: 10.1049/tpe: 19750245 .

[7] Singh, K.; Ahuja, I. P. S. "Ultrasonic machining processesreview paper", International Journal for multi-disciplinary Engineering and Business Management, 2014; 2 (3): 57-66.

[8] Singh, K.; Kumar, V. "A Study on the Tool Geometry and Stresses Induced in Tool in Ultrasonic Machining Process Applied for the Tough and Brittle Materials", International Journal for multi-disciplinary Engineering and Business Management, 2014; 2 (3): 67-71.

[9] Singh, K.; Kumar, V. S. "Finite Element Analysis of Ultrasonic Machine Tool", International journal of engineering research and technology, 2014; 3 (7): 1647-1650.

[10] Singh, K., Ahuja, I. P. S.; Kapoor. J. Study the effect of abrasive and hydrofluoric acid in ultrasonic machining of plain glass material, In proceeding, National Conference Latest Development in Materials, Manufacturing and Quality Control, $19^{\text {th }}-20^{\text {th }}$ February, 2015, GZSCCET, BTI, India， ISBN 978-93-5196-055-3.

[11] Singh, K., Ahuja, I. P. S. and Kapoor. J. Ultrasonic machining of glass brittle material, In proceeding, National Conference Latest Development in Materials, Manufacturing and Quality Control, $19^{\text {th }}-20^{\text {th }}$ February, 2015, GZSCCET, BTI, India, ISBN 978-93-5196-055-3.

[12] Rao, R. V.; Pawar, P. J.; Davim, J. P. Parameter optimization of ultrasonic machining process using nontraditional optimization algorithms. Materials and Manufacturing Processes 2010; 25 (10): 1120-1130. 
[13] Nair, E. V.; Ghosh, A. A fundamental approach to the study of mechanics of ultrasonic machining. International Journal of Production Research 1985; 23: 731-753. http://dx.doi.org/10.1080/00207548508904741

[14] Sahay, C.; Ghosh, S.; Kammila, H. K. Analysis of ultrasonic machining using monte carlo simulation. Proceedings of the ASME 2011 International Mechanical Engineering Congress and Exposition, Denver: USA, 2011. doi: 10.1115/IMECE2011-63240.

[15] Thoe, T. B.; Aspinwall, D. K. Combined ultrasonic and electric discharge machining of ceramic coated nickel alloy. Journal of Materials Processing Technology 1999; 92-93: 323-328. http://dx.doi.org/10.1016/S0924-0136(99)00117-X

[16] Wiercigroch, M.; Neilson, R. D.; Player, M. A. Material removal rate prediction for ultrasonic drilling of hard materials using an impact oscillator approach. Physics Letters 1999; 259: 91-96. http://dx.doi.org/10.1016/S0375-9601(99)00416-8

[17] Thoe, T. B.; Aspinwall, D. K.; Wise, M. L. H. Review on ultrasonic machining. International Journal of Machine Tools and Manufacture 1998; $38 \quad$ (4): 239-255. http://dx.doi.org/10.1016/S0890-6955(97)00036-9

[18] Guzzo, P. L.; Raslan, A. A.; De Mello, J. D. B.) Ultrasonic abrasion of quartz crystals. Wear, 2003; 255: 67-77. http://dx.doi.org/10.1016/S0043-1648(03)00094-2

[19] Komaraiah, M; Narasimha Reddy, P. N, A study on the influence of work-piece properties in ultrasonic machining, International Journal of Machine Tools and Manufacture. 1993; 33 (3): 495-505. http://dx.doi.org/10.1016/0890-6955(93)90055-Y

[20] Jain, N. K.; Jain, V. K. Modeling of material removal in mechanical type of advanced machining processes- a state of the art review. International Journal of Machine Tools and Manufacture 2001; 41: 1573-1635. http://dx.doi.org/10.1016/S0890-6955(01)00010-4

[21] Jain, V. K. Advanced Machining Processes; Allied publishers private limited: New Delhi, India, 2013.

[22] Kumar, J. Ultrasonic machining- a comprehensive review. Machining Science and Technology 2013; 17 (3): 325-379. http://dx.doi.org/10.1080/10910344.2013.806093

[23] Azarhoushang, B.; Akbari, J. Ultrasonic assisted drilling of Inconel 738-LC. International Journal of Machine Tools and Manufacture 2007; 47: 1027-1033.

http://dx.doi.org/10.1016/j.ijmachtools.2006.10.007

[24] Haslehurst, M. Manufacturing Technology, 3rd edition, Viva Book, New Delhi, 1981, pp. 270-271.

[25] Weilong, C; Zhijian. P, Process of Ultrasonic Machining, Handbook of manufacturing Engineering and Technology, London, 2013.

[26] Choi, J. P.; Jeon, B. H.; Kim, B. H. Chemical-assisted ultrasonic machining of glass. Journal of Materials Processing Technology, 2007; 2191 1 $23-156$. http://dx.doi.org/10.1016/j.jmatprotec.2007.03.017

[27] Morteza, A. S; Maohammad, N. R, Development of design and manufacturing support tool for optimization of ultrasonic machining (USM) and Rotary USM, Journal of Modern processes in manufacturing and production, 2014; 3 (2): 59-74.
[28] Vinod, Y; Aniruddha, D. Design of horn for rotary ultrasonic machining using the finite element method, International journal of advanced manufacturing technology, 2008; 39 (1): 9-20 DOI: 10.1007/s00170-007-1193-7.

[29] H. Hong, T. Y. Hung, Advanced analysis of Nontraditional machining, Springer, (1956); 325-339, ISBN 978-1-4614-4054-3. DOI: 10.1007/978-1-4614-4054-3.

[30] Soundararajan, V; Radhakrishnan, V. An experimental investigation on the basic mechanisms involved in ultrasonic machining, International Journal of Machine Tool Design and Research, 1986; 26 (3): 307-321. http://dx.doi.org/10.1016/0020-7357(86)90008-9

[31] Weller, E. J. Non-traditional Machining Processes, 2nd edition, American Society of tool and Manufacturing Engineers, 1984; $15-71$

[32] Guzzo, P. L.; Shinohara, A. H.; Raslan, A. A. A comparative study on ultrasonic machining of hard and brittle materials, Journal of the Brazilian Society of Mechanical Science and Engineering, 2004; 26 (1): 56-61, ISSN 1806-3691. doi.org/10.1590/S1678-58782004000100010.

[33] Adithan, M. Tool wear characteristics in ultrasonic drilling, Tribology International, 1981; 14 (6): 351-356. http://dx.doi.org/10.1016/0301-679X(81)90103-1.

[34] Goetze, D. Effect of vibration amplitude, frequency and composition of the abrasive slurry on the rate of ultrasonic machining in Ketos tool steel, Journal of acoustical society of America, 1956; 28 (6): 1033-1037 Doi: http://dx.doi.org/10.1121/1.1908545

[35] Adithan, M. Abrasive wear in ultrasonic drilling, Tribology International, 1983; 16 (5): 253-255. http://dx.doi.org/10.1016/0301-679X(83)90083-X

[36] Adithan, M.; Venkatesh, V. C. Parameter influence on tool wear in ultra-sonic drilling, Tribolology International, 1974; 7 (6): 260-264. http://dx.doi.org/10.1016/0041-2678(74)90106-7

[37] Babitsky, V. I.; Astashev, V. K. Ultrasonic processes and machine, Springer Berlin Heidelberg New York, (2007) ISBN 978-3-540-72060-7.

[38] Jain, N. K.; Jain, V. K. Modeling of material removal in mechanical type advanced machining processes: a state of art review, International journal of machine tools and manufacture, 2001; $\quad 41 \quad$ (11): $\quad 1573-1635$ http://dx.doi.org/10.1016/S0890-6955(01)00010-4

[39] M. A. Moreland, Ultrasonic Machining and Finishing, ASM Handbook, Ceramics and Glasses, 1989: 16: 359-362, ISBN 978-0-87170-022-3.

[40] Thoe, T. B.; Aspinwall, D. K.; Wise, M. L. H., Review on ultrasonic machining, International journal of machine tools and manufacture, 1998; 38 (4): 239-255 http://dx.doi.org/10.1016/S0890-6955(97)00036-9

[41] T. J. Drozda, C. Wick, Non-traditional machining, Tool and Manufacturing Engineers Handbook, Society of Manufacturing Engineers, Vol. 1, Dearborn, MI, 1983, pp. 1-23, ISBN No. 0872633519 .

[42] Neppiras, E. A. Macrosonics in industry 1. Introduction, Ultrasonics, $\quad 1972 ; \quad 10 \quad$ (1): http://dx.doi.org/10.1016/0041-624X(72)90207-7 
[43] Seah, K. H. W.; Wong, Y. S.;. Lee, L. C. Design of tool holders for ultra-sonic machining using FEM, Journal of Material Processing Technology. 1993; 37 (1-4): 801-816. http://dx.doi.org/10.1016/0924-0136(93)90138-V

[44] Komaraiah, M.; Manan, M. A.;. Reddy, P. N.; Victor, S. Investigation of surface roughness and accuracy in ultrasonic machining, Precision Engineering, 1988; 10 (2): 59-65. http://dx.doi.org/10.1016/0141-6359(88)90001-3

[45] Neppiras, E. A. Ultrasonic machining and forming, Ultrasonics 1964; 2 (4): 167-173. http://dx.doi.org/10.1016/0041-624X(64)90110-6

[46] Prewo, K. M.; Brennan, J. J.; High Strength silicon carbide fiber-reinforced glass-matrix composites, Journal of material science, 1980; 15 (2): 463-468. DOI: 10.1007/BF00551699.

[47] Thoe, T. B.; Aspinwall, D. K.; Wise, M. L. H. The effect of operating parameters when ultrasonic contour machining, in: Proceedings of the 12th Annual Conference of the Irish Manufacturing Committee (IMC-12), Cork, Ireland, September, 1995 ; 305-312.

[48] Adithan, M. Tool wear studies in ultrasonic drilling, Wear, 1974; 29: 81-93. http://dx.doi.org/10.1016/0043-1648(74)90136-7

[49] Kainth, G. S.; Nandy, A.; Singh, K. On the mechanics of material removal in ultrasonic machining, International Journal of Machine Toll Design And Research, 1979; 19 (1): 33-41. http://dx.doi.org/10.1016/0020-7357(79)90019-2

[50] Jain, V. K. Advanced Machining Process, Allied Publisher Pvt. Limited, India, 2002, pp. 28-56.

[51] Miller, G. E. Special Theory of Ultrasonic Machining, Journal of applied physics, 1957; 28 (2): 149-156. http://dx.doi.org/10.1063/1.1722698

[52] Neppiras, E. A.; Foskett, R. D. Ultrasonic machining, Phillips Technical Review, 18 (11) (1957) 325-368.

[53] Pandey, P. C.; Shan, H. S. Modern Machining Processes, Tata McGraw-Hill, 1980, pp. 7-38 [Chapter 2].

[54] Amin, S. G.; Ahmed, M. H. M.; Youssef, H. A. Computer aided design of acoustic horns for ultrasonic machining using finite element analysis, Journal of material processing technology, 1995; 55: 254-260. http://dx.doi.org/10.1016/0924-0136(95)02015-2

[55] Cook, N. H. Manufacturing Analysis, Addison-Wesley, New York, 1966; 133-138.

[56] Graff, K. F. Macrosonics in industry. 5. Ultrasonic machining, Ultrasonics, 1975; 13: 103-109. http://dx.doi.org/10.1016/0041-624X(75)90060-8

[57] Kremer, D. The state of the art of ultrasonic machining, Ann. CIRP, 1981; 30 (1): 107-110. http://dx.doi.org/10.1016/S0007-8506(07)60905-6

[58] Khairy, A. B. E. Assessment of some dynamic parameters for the ultra-sonic machining process, Wear, 1990; 137: 187-198 http://dx.doi.org/10.1016/0043-1648(90)90135-W

[59] Singh, K., Ahuja, I. P. S. and Kapoor. J. Comparative study between conventional machining, chemical ultrasonic machining (CUSM) and ultrasonic machining (USM) of plain glass, polycarbonate, acrylic, bullet proof and heat resistant glass, In proceeding, International conference in latest development in materials, manufacturing and quality control, 12th -13th Feb-2016, GZSCCET BTI India, ISSN 978-93-5212-858-7.

[60] Jain, V.; Sharma, A. K.; Kumar, P. Investigations on tool wear in micro Ultrasonic machining, Applied Mechanics and Material, Tranc Tech Publication Switzerland, 2012; 110-116: $1561-1566$

DOI: 10.4028/www.scientific.net/AMM.110-116.1561.

[61] I. Kaczmarek, Impact Grinding (Ultrasonic machining)—Book Chapter: 21 Principles of Machining by Cutting Abrasion and Erosion, Peter Peregrinus Ltd, Stevenage, 1976; 448-462, ISBN 0901223662.

[62] Dharmadhikari, S. W.; Sharma, C. S. Optimization of abrasive life in Ultrasonic Machining, Journal of Manufacturing Science and Engineering, 1985; 107 (4): 361-364. doi: 10.1115/1.3186010.

[63] Bekrenev, N. V.; Muldasheve, G. K.; Petrovskii, A. P.; Tsvetkova, O. A. Influence of the thermal effect on the cutting forces in the ultrasonic machining of high strength material, Russian Engineering Research, ISSN 1068-798X, 2015; 35 (10): pp. 758-759 DOI: 10.3103/S1068798X15100056.

[64] Hasiao, Y. F., Tarng, Y. S. and Huang, W. J. Optimization of plasma are welding parameters by using the Taguchi method with the Grey relational analysis. Materials and manufacturing $\begin{array}{lll}\text { processes } 2008, & 23, & \end{array}$ doi.org/10.1080/10426910701524527.

[65] Lin, C. L., Lin, J. L. and Ko, T. C. Optimisation of EDM process based on the orthogonal array with fuzzy logic and grey relational analysis method. International journal of advanced manufacturing technology 2002; 19: 271-277. doi: $10.1007 / \mathrm{s} 001700200034$.

[66] You, M. L., Shu, C. M., Chen, W. T. and Shyu, M. L. Analysis of cardinal grey relational grade and grey entropy on achievement of air pollution reduction by evaluating air quality trend in Japan. Journal of cleaner production 2017; 142 (4): 3883-3889. doi.org/10.1016/j.jclepro.2016.10.072.

[67] Patil, P. J. and Patil, C. R. Analysis of process parameters in surface grinding using single objective Taguchi and multi-objective grey relational grade. Perspective in Science 2016; 8: 367-369. doi.org/10.1016/j.pisc.2016.04.077.

[68] Ahmad, N., Kamal, S., Raza, Z. A. and Hussain, T. Multi-response optimization in the development of oleo-hydrophobic cotton fabric using Taguchi based grey relational analysis. Applied surface science 2016; 367: 370-381. doi.org/10.1016/j.apsusc.2016.01.165.

[69] Lin, Y. H., Lee, P. C. and Chang, T. P. Practical expert diagnosis modal based on the grey relational analysis technique. Expert system with applications 2009; 36: 1523-1528. doi.org/10.1016/j.eswa.2007.11.046.

[70] Lin, H. L. The use of the Taguchi method with grey relational analysis and a neural network to optimize a novel GMA welding process. Journal of intelligent manufacturing 2012; 23 (5): 1671-1680. doi: 10.1007/s10845-010-0468-2.

[71] Manivannan, S., Prasanna, S. and Aramugam, R. Multi-objective optimization of flat plate heat sink using Taguchi based grey relational analysis. International journal of advanced manufacturing technology 2011; 52: 739-749. DOI: 10.1007/s00170-010-2754-8. 
[72] Meena, V. K. and Azad, M. S. Grey relational analysis of micro EDM machining of Ti-6Al-4V alloy. Material and manufacturing processes 2012; 27: 973-977. doi.org/10.1080/10426914.2011.610080.

[73] Singh, P. N., Raghukandan, K. and Pai, B. C. Optimization by grey relational analysis of EDM parameters on machining $\mathrm{Al}-10 \% \mathrm{SiCp}$ composites. Journal of material processing technology 2004; 155-156: 1658-1661. doi.org/10.1016/j.jmatprotec.2004.04.322.

[74] Sreenivasulu, R. and Srinivasarao, C., 2012. Application of Grey relational analysis for surface roughness and roundness error in drilling of AL 6061 alloy. International journal of lean thinking 2012; 3 (2): 68-78.

[75] Chang, S.; Bone, G. M. Burr size reduction in drilling by ultrasonic assistance. Robotics and Computer-Integrated Manufacturing, 2005, 120, 442-450.

[76] Fan, W. H.; Chao, C. L.; Chou, W. C.; Chen, T. T; Chao, C. W. Study on the Surface Integrity of Micro-Ultrasonic Machined Glass-Ceramic Material, Key Engineering Materials, 2009; 407-408: 731-734. DOI: 10.4028/www.scientific.net/KEM.407-408.731.

[77] Kumar, J.; Khamba, J. S. An Investigation into the effect of work material properties, tool geometry and abrasive properties on performance indices of ultrasonic machining. International Journal of Machining and Machinability of Materials, 2009; 5 $(2 / 3)$ : $347-365$. http://dx.doi.org/10.1504/IJMMM.2009.023399.

[78] Schorderet, A. Deghilage, E. Agbeviade, K. tool type and hole diameters influence in deep ultrasonic drilling of micro holes in glass, Procedia CIRP, 2013; 565-570. http://dx.doi.org/10.1016/j.procir.2013.03.072

[79] Elliot, S. R. Physics of Amorphous Materials. Longman group ltd, London, New York, 1984; 20 (9): ISBN 0-582-44636-8.

[80] Scholze, H. Glass - Nature, Structure, and Properties. Springer, Verlag, New York, (1991) ISBN 978-1-4613-9069-5. DOI: 10.1007/978-1-4612-9069-5.

[81] Phillips, J. C. Topology of covalent non-crystalline solids I: Short-range order in chalcogenide alloys, Journal of Non-Crystalline Solids. 1979; 34 (2): 153-181.

[82] Folmer, J. C. W., Franzen, S. Study of polymer glasses by modulated differential scanning calorimetry in the undergraduate physical chemistry laboratory, Journal of Chemical Education. 2003; 80 (7): 813-818. DOI: 10.1021/ed080p813.

[83] Phillips D. C, Sambell R. A. J, Bowen D. H, The mechanical properties of carbon fiber reinforced pyrex glass, Journal of Material Science, 1972; 7 (12): 1454-1464. DOI: 10.1007/BF00574937.

[84] "Dr Karl's Homework: Glass Flows" Australia: ABC. 26 January 2000. Retrieved 24 October 2009.

[85] Dutra, Z. E. Do Cathedral Glasses Flow? American Journal of Physics, 66 (5) (1998), pp. 392-396.

[86] Vogel, W.; Kreidl, N.; Chemistry of Glass, Wiley, 1985. ISBN 978-0-916094-73-7.

[87] Stookey, S. D.; Beall, G. H. Explorations in Glass: An Autobiography, Wiley, 2000, ISBN 978-1-57498-124-7.

[88] Noel C. Stokes, The Glass and Glazing Handbook, Standards Association of Australia, (1998) ISBN 073372468X.

[89] L. D. Rozenberg (Ed.), Physical Principles of Ultrasonic Technology, vols. 1 and 2, Plenum Press, New York, 1973, ISBN 978-1-4684-8217-1.

[90] Ultrasonic machining of glass at the N. P. T. L., Machinery, May 1964, pp. 1172-1176.

[91] William. S.; Jayad. H. Foundation of material science and engineering, 4tg Ed. McGraw-Hill. Pp. 509. ISBN 0-07-295358-6.

[92] Harper, C. A.; Petrie, E. M. Plastic materials and processes: A concise encyclopaedia, John Wiley and Sons, pp. 9, ISBN 978-0471-45920-0

[93] V. C. Venkatesh, Machining of glass by impact processes, Journal of Mechanical Working Technology, 1983, 8, 247-260 http://dx.doi.org/10.1016/0378-3804(83)90042-6

[94] D. E. Clark, C. G. Pantano, Jr., L. L. Hench, Corrosion of Glass, Books for Industry, 1979.

[95] A. Paul, Chemistry of Glasses, $2^{\text {nd }}$ Edition, Chapman and Hall, London, New York, 1990, ISBN 0-412-27820-0.

[96] Guzzo, P. L.; Raslan, A. A.; DeMello, J. D. B.) Ultrasonic abrasion of quartz crystals. Wear, 2003; 255: 67-77. http://dx.doi.org/10.1016/S0043-1648(03)00094-2

[97] Kuo, K. L. Experimental investigation of brittle material milling using rotary ultrasonic machining. Proceedings of the 35th International MATADOR Conference, Springer: London, 2007, 195-198. DOI: 10.1007/978-1-84628-988-0_43.

[98] Hasani, H., Tabatabaei., S. A. and Amiri, G. Grey relational analysis to determine the optimum process parameters for open end sprnning yarns. Journal of engineering fibers and fabrics 2012; 7 (2): 81-86. 